\title{
\begin{tabular}{l|l} 
Mibraries & DSpace@MIT
\end{tabular}
}

\author{
MIT Open Access Articles
}

Exhumation of the UHP Tso Morari eclogite as a diapir rising through the mantle wedge

The MIT Faculty has made this article openly available. Please share how this access benefits you. Your story matters.

Citation: Chatterjee, Nilanjan, and Oliver Jagoutz. "Exhumation of the UHP Tso Morari Eclogite as a Diapir Rising through the Mantle Wedge." Contributions to Mineralogy and Petrology 169.1 (2015): n. pag.

As Published: http://dx.doi.org/10.1007/s00410-014-1099-y

Publisher: Springer Berlin Heidelberg

Persistent URL: http://hdl.handle.net/1721.1/107266

Version: Author's final manuscript: final author's manuscript post peer review, without publisher's formatting or copy editing

Terms of use: Creative Commons Attribution-Noncommercial-Share Alike 
Nilanjan Chatterjee, Oliver Jagoutz

\section{Exhumation of the UHP Tso Morari eclogite as a diapir rising through the mantle wedge}

Nilanjan Chatterjee, Oliver Jagoutz

Department of Earth, Atmospheric, and Planetary Sciences, Massachusetts Institute of Technology, Cambridge, Massachusetts 02139, U.S.A. E-mail: nchat@mit.edu, jagoutz@ mit.edu, Phone: +1-617-253-1995

Abstract Ultrahigh pressure (UHP) rocks such as the coesite-bearing eclogites, occurring as boudins within felsic gneisses of the Tso Morari dome in northwestern Himalayas, originated through subduction of the northern continental margin of India during its Early Eocene collision with the Kohistan-Ladakh arc. These rocks are believed to be exhumed through a low-viscosity channel along the top surface of the subducting slab. However, details of the exhumation mechanism are poorly known. We present new constraints on the $P$-T evolution of hydrous and carbonate-rich samples of the Tso Morari eclogite between $2.2-2.3 \mathrm{GPa} / 400-425{ }^{\circ} \mathrm{C}$ and $\sim 0.4 \mathrm{GPa} / 450{ }^{\circ} \mathrm{C}$ using thermobarometry and calculated $P-T-\mathrm{M}_{\mathrm{CO} 2}$ phase equilibria. Our results indicate that the eclogites were strongly heated at high pressures from $400-425{ }^{\circ} \mathrm{C}$ at $2.2-2.3 \mathrm{GPa}$ to $670-720{ }^{\circ} \mathrm{C}$ at $1.8-1.9 \mathrm{GPa}$ during the early stages of exhumation. Diffusion modeling of $\mathrm{Ca}$ variation across the core-rim interface of garnet indicates that the heating stage lasted only $<0.1 \mathrm{Myr}$, in accordance with geochronological constraints and fast exhumation rates. Our $P-T$ path is at odds with exhumation of the eclogites along a subduction channel as model 
calculations indicate that the intermediate $P-T$ conditions of $1.8-1.9 \mathrm{GPa} / 670-720{ }^{\circ} \mathrm{C}$ are not achieved along the subducting slab. Instead, the constrained $P-T$ conditions are consistent with heating within the mantle wedge overlying the subducting slab. Therefore, we conclude that the Tso Morari eclogites were possibly exhumed as part of a low density, felsic diapir rising through the mantle wedge. Based on low viscosity values $\left(1.7 \times 10^{19}\right.$ to $\left.5.0 \times 10^{19} \mathrm{~Pa} . \mathrm{s}\right)$ of mantle wedges associated with modern subduction zones, the calculated exhumation rate for the Tso Morari eclogite is extremely fast (29-147 $\mathrm{mm} / \mathrm{yr}$ ) and at par with that constrained for other northwestern Himalayan UHP rocks.

Keywords: Tso Morari; eclogite; Himalaya; metamorphism; exhumation; mantle wedge

\section{Introduction}

The process of exhumation of continental ultrahigh pressure (UHP) rocks is not well understood, though several geodynamic mechanisms such as crustal stacking, channel flow, trans-mantle diapirs, and incorporation within a collisional orogen have been proposed (Gerya et al. 2002, 2004, Faccenda et al. 2008, Behn et al. 2011, Hacker et al. 2011, Vogt et al. 2013, Hacker and Gerya 2013, and references therein). According to early researchers, UHP rocks such as eclogite are exhumed to the base of the lower crust through the "subduction channel", a wedge-shaped low-viscosity zone along the interface between the subducting slab and the overlying mantle wedge (Cloos and Shreve 1988, Guillot et al. 2001). Numerical simulations have shown that such a mechanism is relevant in the exhumation of subducted oceanic crust (Gerya et al. 2002). However, subduction channels are characterized by a thermal gradient (Gerya et al. 2002, Syracuse et al. 2010), and previous studies on the Tso Morari UHP rocks of northwestern Himalayas (Fig. 1) 
representing exhumed Indian continental crust show isothermal decompression in their $P$ $T$ paths of metamorphism (cf. de Sigoyer et al. 1997, Guillot et al. 1997, St-Onge et al. 2013). Furthermore, the lower pressure conditions of isothermal decompression (see below) do not exist along the top surface of subducting slabs (cf. Syracuse et al. 2010). Thus, $P-T$ paths based on metamorphic equilibria are not consistent with exhumation of the Tso Morari eclogites through a subduction channel. Nevertheless, an isothermal decompression path and exhumation through the subduction channel may be reconciled in terms of fast exhumation rates (e.g., $>12 \mathrm{~mm} / \mathrm{yr}$, St-Onge et al. 2013) and disequilibrium processes. On the other hand, more recent numerical simulations (Gerya et al. 2004, Behn et al. 2011, Vogt et al. 2013), petrological modeling (Hacker et al. 2011), and field evidence (Papua New Guinea, Little et al. 2011) have shown the possibility of exhumation of continental UHP rocks through diapirism within the mantle wedge, or through the formation of a continental collisional orogen (Faccenda et al. 2008).

Previously determined $P-T$ conditions of metamorphism for the Tso Morari eclogites are widely variable (Fig. 2). Using mineral thermometers (e.g., Grt-Cpx Fe-Mg exchange) and barometers (Si-in-phengite, Jd-in-omphacite), de Sigoyer et al. (1997) calculated that the eclogitic garnet cores and rims equilibrated at pressures of $2.0 \pm 0.3$ GPa and $1.1 \pm 0.2 \mathrm{GPa}$, respectively, at a constant temperature of $580 \pm 60{ }^{\circ} \mathrm{C}$ suggesting isothermal decompression. On the other hand, St-Onge et al. (2013) used P-T pseudosection analysis to conclude that their eclogitic garnet cores and rims equilibrated at $2.15 \pm 0.15 \mathrm{GPa} / 535 \pm 15{ }^{\circ} \mathrm{C}$ and $\sim 2.7 \mathrm{GPa} / 630-645{ }^{\circ} \mathrm{C}$, respectively, suggesting a $P$ $T$ increase for the garnet rim growth. Their thermobarometric calculation also suggests that the garnet rims equilibrated at similar conditions of $\sim 2.55 \mathrm{GPa} / 602-617{ }^{\circ} \mathrm{C}$. The 
evidence for near-isothermal decompression in St-Onge et al. (2013) comes from the felsic gneisses surrounding the Tso Morari eclogite lenses that yielded a $P-T$ of $1.25 \pm$ $0.05 \mathrm{GPa} / 690 \pm 25{ }^{\circ} \mathrm{C}$ (their M3 stage), suggesting that the UHP assemblages decompressed from $\sim 2.7 \mathrm{GPa}$ to $1.25 \mathrm{GPa}$ within a small temperature range of $\sim 60{ }^{\circ} \mathrm{C}$. Thus, the garnet rims in eclogite yield very different $P-T$ results in the two studies.

The different $P$ - $T$ results obtained in the two studies mentioned above may be due to the differences in compositions of the minerals and their zoning patterns in the eclogite samples examined. For example, eclogitic garnet in de Sigoyer et al. (1997) does not show a well-defined core and the center-to-rim zoning pattern is gradational. The center is $\mathrm{Ca}$-Fe-rich ( $\left.\operatorname{Prp}_{12} \mathrm{Alm}_{67} \mathrm{Grs}_{30} \mathrm{Sps}_{3}\right)$ that smoothly grades into an $\mathrm{Mg}$-rich outer rim $\left(\operatorname{Prp}_{38} \mathrm{Alm}_{41} \mathrm{Grs}_{13} \mathrm{Sps}_{6}\right)$. On the other hand, the eclogitic garnet in St-Onge et al. (2013) consists of large core domains of nearly constant composition $\left(\operatorname{Prp}_{7-12} \mathrm{Alm}_{60-67} \mathrm{Grs}_{24-}\right.$ ${ }_{30} \mathrm{Sps}_{3-4}$ ) and distinct, complexly zoned rims (outer rim: $\operatorname{Prp}_{\sim 35} \mathrm{Alm}_{\sim 50} \mathrm{Grs}_{\sim 19} \mathrm{Sps}_{0}$ ) that are significantly higher in grossular and almandine, and somewhat lower in pyrope. However, the omphacite compositions in both studies are similar $\left(\mathrm{Jd}_{41-50}\right.$ in de Sigoyer et al. 1997, $\mathrm{Jd}_{44-50}$ in St-Onge et al. 2013). Thus, the different $P$ - $T$ results in the two studies may be sample-dependent.

An additional difference in the $P$ - $T$ paths presented in the previous studies of the Tso Morari eclogite pertains to a thermal overprint that is commonly attributed to Barrovian metamorphism during the later Himalayan orogeny. Both studies cited above concluded that the Tso Morari UHP rocks experienced a crustal heating episode (610 \pm $70{ }^{\circ} \mathrm{C}$ at $0.9 \pm 0.3 \mathrm{GPa}$, de Sigoyer et al. $1997 ; 725 \pm 50{ }^{\circ} \mathrm{C}$ at $0.71 \pm 0.1 \mathrm{GPa}$, St-Onge et 
al. 2013) before cooling in the upper crust. However, a third study concluded that the eclogites continuously cooled from $\sim 800-900{ }^{\circ} \mathrm{C}$ at $3.3-4.6 \mathrm{GPa}$ to $\sim 400{ }^{\circ} \mathrm{C}$ at $\sim 0.4 \mathrm{GPa}$ without any intermediate heating (Mukherjee et al. 2003). Thus, the presence or absence of the Barrovian overprint may also be sample-dependent.

In this paper, we use thermobarometry as well as $P-T-\mathrm{M}_{\mathrm{CO} 2}$ pseudosection analysis to constrain the $P-T$ path of metamorphism of additional hydrous and carbonaterich samples of the Tso Morari eclogite. Our results show that the eclogites were strongly heated during the early stages of exhumation. The $P-T$ paths determined in this and earlier studies are highly variable, and none of them shows cooling associated with decompression as would be expected if exhumation occurred through a subduction channel. These $P-T$ paths may be explained by exhumation involving a diapiric rise of the eclogitic rocks from the subducted Indian crust through the overlying mantle wedge. Such an exhumation model is also consistent with field evidence.

\section{Geological Setting}

UHP eclogites are known in the Himalaya only from the northwestern part (the Tso Morari and Kaghan eclogites in northern India and Pakistan, respectively) where the Indian plate collided initially with the so-called Kohistan-Ladakh island arc at $50.1 \pm 1.5$ Ma (cf. Zhu et al. 2005) and finally with Asia 10 Myr later at 40.4 $\pm 1.3 \mathrm{Ma}$ (Bouilhol et al. 2013). The Tso Morari dome hosting the eclogites is exposed in the northwestern Himalayas between the Indus Suture Zone to the northeast and the Zanskar Tethys Himalaya to the southwest (Fig. 1). The core of the dome consists of Cambro-Ordovian felsic augen gneisses (Puga Formation) overlain by Cambrian-Devonian quartzites, 
schists and conglomerates, which are in turn structurally overlain by Lower Carboniferous-Triassic marine dolomitic marbles and metapelites (Berthelsen 1953, Virdi et al. 1978). The mafic eclogites are intercalated with the felsic orthogneiss and metasediments, and occur as up to tens of meter-thick boudins parallel to the foliation. Coesite inclusions with prominent radial fractures in their host garnet indicate the UHP metamorphic conditions of the eclogites (Sachan et al. 2004). The Tso Morari unit is separated from the surrounding rocks by ductile normal shear zones. The northeast dipping Zildat shear zone separates the Tso Morari unit from the low-grade metamorphic rocks of the Indus Suture Zone and the Early Cretaceous Nidar ophiolite in the northeast, whereas the south dipping Karzog shear zone separates the dome from the less metamorphosed Mata-Karzog unit, and the Karzog and related ophiolites at its southwestern margin (Berthelsen 1953, de Sigoyer et al. 2004, Mahéo et al. 2004, Epard and Steck 2008). Whole rock and mineral isotope ages of the Tso Morari eclogites (47-55 Ma, de Sigoyer et al. 2000, Leech et al. 2005, St-Onge et al. 2013, Donaldson et al. 2013) are consistent with the U-Pb zircon, allanite and titanite ages of the Kaghan eclogites (4450 Ma, Kaneko et al. 2003, Parrish et al. 2006, Wilke et al. 2010).

The Tso Morari unit shows evidence of three deformation phases (D1, D2, and D3, Thakur 1983; de Sigoyer et al. 2004). D1 is characterized by steep tight to isoclinal folds (F1) with a subvertical axial plane cleavage (S1) defined by garnet and omphacite in the central part of the unit. The pervasive D2 deformation is characterized by recumbent isoclinal to open folds (F2) and shallow dipping S2-L2 structures. The S2 schistosity is subhorizontal in the central part and steeper near the edges of the dome. S2 is associated with a NW-SE lineation (L2) parallel to the long axis of the Tso Morari 
dome suggesting horizontal stretching along a NW-SE direction during the D2 deformation. The D3 deformation is mainly localized at the edges of the dome in the Zildat and Karzog shear zones, and its strain relations suggest a subvertical uplift of the Tso Morari dome through the upper crust. The dome geometry of the Tso Morari unit can be attributed to compression during D1 and D2, the main stage of exhumation occurred during D2, and end of exhumation was controlled by D3 (de Sigoyer et al. 2004).

Epard and Steck (2008) proposed a buoyancy-driven extrusion of the Tso Morari unit from a subduction zone in the form of a nappe stack. Boudinage and concentric folding of basaltic dikes hosted within the Cambro-Ordovian gneisses represent a preeclogite stage of deformation, whereas three dominant schistosites with W-E oriented (L1), N-directed (L2) and NE-directed (L3) stretching lineations are related to the extrusion of the nappe stack after eclogitization. The last two structural overprints are related to an early $\mathrm{N}$ - and a later NE-directed underthrusting of the Indian plate below Asia accompanied by an anticlockwise rotation of India.

\section{Analytical Methods}

Back-scattered electron (BSE) images, elemental X-ray maps, and chemical compositions of minerals were obtained on a JEOL JXA-8200 Superprobe electron probe microanalyzer at Massachusetts Institute of Technology, Cambridge, USA. The minerals were analyzed by wavelength dispersive spectrometry (WDS) using an accelerating voltage of $15 \mathrm{kV}$, a beam current of $10 \mathrm{nA}$, and 40-60 s counting times per element. Typical $1 \sigma$ standard deviation of counts was between 0.5 and $1 \%$. The raw data were corrected for

matrix effects with the CITZAF package (Armstrong 1995) using the $\phi \rho z$ method 
(stopping power, back-scatter corrections and $\phi(0)$ from Love and Scott, mean ionization potential from Berger and Seltzer, Heinrich's tabulation of mass absorption coefficients, and Armstrong's modified equations for absorption and fluorescence corrections). Representative analyses of the minerals are shown in Table 1 and Supplementary Tables 1-4 (see Online Resource) and all analyses are plotted in Fig. 3. Texture-specific mineral compositions used in thermobarometric calculations are provided in Table 2. To estimate the modal abundance of phases, several X-ray maps and BSE images of representative areas of each sample were digitally analyzed and the results were averaged (Table 3). Ten X-ray maps, five with WDS and five with the energy dispersive spectrometer (EDS), and a BSE image were collected simultaneously of each area. The bulk compositions were calculated by combining the mineral compositions with their modal abundances. $\mathrm{H}_{2} \mathrm{O}$ was estimated by using the difference between the analytical total and 100 for the hydrous phases, and $\mathrm{CO}_{2}$ was estimated using oxide stoichiometry in the carbonates.

\section{Mineral compositions and texture}

Two representative Tso Morari eclogite samples hosted within orthogneiss from the center of the dome, south of Puga ( $33^{\circ} 10^{\prime} 59.32^{\prime \prime}$ Latitude, $78^{\circ} 21^{\prime} 25.17^{\prime \prime}$ Longitude, Fig. 1), LB09-8.1 and LB09-9.3, were studied in detail (Figs. 3-6). These samples are foliated and predominantly comprised of garnet and omphacite (LB09-8.1: $\mathrm{Jd}_{30-50} \mathrm{Aug}_{50-}$ ${ }_{60} \mathrm{Aeg}_{<15} ; \mathrm{LB} 09-9.3: \mathrm{Jd}_{37-60} \mathrm{Aug}_{40-60} \mathrm{Aeg}_{<10} ; \mathrm{Jd}-$ jadeite; Aug-augite; Aeg-aegirine; Fig. 3) porphyroblasts surrounded by thin amphibole (ferropargasite, taramite and minor gedrite) and/or mica (biotite and phengite) rinds, as well as fine-grained intergrowths of albitic plagioclase, actinolite (Mg\# 77) and augite ( $\left.\operatorname{Aug}_{88}\right)$ in LB09-8.1 (Fig. 4g), and biotite 
(Mg\# >62), pargasite $\left(\mathrm{Mg \#} \mathrm{71)}\right.$ and plagioclase $\left(\mathrm{An}_{<23}\right)$ in LB09-9.3. The matrix is dominated by prismatic barroisite, epidote/zoisite, paragonite, phengite (Si 3.4-3.6 pfu) and intergrowths of dolomite-calcite. Both samples are rich in the carbonates, which occupy 5-12\% of the matrix by volume (Fig. 4c, Table 3 ). Kyanite and magnesite are present in the matrix of LB09-9.3 in minor amounts, and rutile, apatite, zircon are present in accessory amounts.

The euhedral, 0.2-2.0 mm-sized garnet porphyroblasts consist of distinct Ca-Ferich cores (LB09-8.1: Grs 33-27 $\operatorname{Prp}_{6-11} \mathrm{Alm}_{59-66} \mathrm{Sps}_{4-1}$; LB09-9.3: Grs $_{35-24} \operatorname{Prp}_{10-22} \mathrm{Alm}_{7-}$ ${ }_{60} \mathrm{Sps}_{0.5-1.5} \mathrm{Adr}_{3-1}$ ) surrounded by 50-100 $\mu$ m-thick, zoned Mg-rich rims (LB09-8.1: Grs ${ }_{18-}$ ${ }_{25} \operatorname{Prp}_{14-25} \operatorname{Alm}_{66-48} \operatorname{Sps}_{2.0-0.5}$; LB09-9.3: Grs $_{16-13} \operatorname{Prp}_{25-35} \mathrm{Alm}_{60-50} \operatorname{Sps}_{1.0-0.5} \operatorname{Adr}_{2.5-0.5}$ ) (Figs. 5 and 6). The grossular content decreases and the pyrope content increases sharply at the core-rim boundary. In the garnet rim of LB09-8.1 (Fig. 5), grossular shows a gradual increase followed by a small decrease in the outer rim. Pyrope decreases up to the midrim, but sharply changes trend to increase toward the outer rim. The garnet rim of LB099.3 shows similar but are less pronounced compositional trends (Fig. 6). The cores are rich in inclusions ranging from large polymineralic aggregates to small monomineralic inclusions (Figs. 4d, 5b and 6b). Inclusions are rare in the rims. In LB09-8.1, the contact zone of garnet surrounding the polymineralic inclusions has approximately the same composition as the outer rim of the garnet. Small recrystallized garnet $\left(\operatorname{Prp}_{27}\right)$ similar in composition to the garnet rim also occurs within the polymineralic inclusions (Fig. 4d). The other minerals in the inclusions are amphibole, epidote/zoisite, paragonite, phengite, dolomite/calcite, quartz, rutile, ilmenite and zircon in the order of decreasing abundance. Silica inclusions with fractures radiating into the host garnet (Fig. 4e) possibly contains 
high- $P$ coesite relics (cf. O'Brien et al. 2001, Sachan et al. 2004). An omphacite inclusion was found at the core-rim contact of one garnet porphyroblast (Fig. 5b). The carbonates comprise as much as 14.5 volume \% of the inclusions in LB09-8.1. In LB09-9.3, the inclusions within the garnet core are dominated by barroisite, taramite and pargasite amphiboles with subordinate amounts of zoisite, phengite, paragonite, quartz, rutile, ilmenite and dolomite. Some garnet porphyroblasts contain veins of taramite and biotite connected to the biotite rind outside the garnet (Fig. 6b). The garnet core shows patchy zoning, but the composition of the contact zones of the garnet with the inclusions is not significantly different from the composition of the rest of the garnet core.

\section{Thermobarometry}

The thermobarometer applicable for the garnet + clinopyroxene + phengite + kyanite + $\mathrm{SiO}_{2}$ assemblage in eclogite (Ravna and Terry 2004) was used to calculate the $P-T$ of equilibrium of the core and rim domains of garnet with the corresponding domains of neighboring omphacite and phengite (Table 2, Fig. 7). In the absence of kyanite except in the matrix of LB09-9.3, the calculations are based on the garnet-clinopyroxene Fe-Mg exchange thermometer and the garnet-clinopyroxene-phengite barometer. The $P-T$ conditions obtained for the porphyroblast cores in LB09-8.1 and LB09-9.3 are 2.46 GPa and $458{ }^{\circ} \mathrm{C}$, and $2.24 \mathrm{GPa}$ and $480{ }^{\circ} \mathrm{C}$, respectively. The core domains of the garnet and omphacite porphyroblasts are shielded from lower temperature Fe-Mg exchange during the later stages of metamorphism. Thus, the core domains yield the most reliable $P-T$ estimates assuming that they formed in equilibrium. 
The outer rims of the porphyroblasts in LB09-8.1 yielded a $P-T$ of $2.68 \mathrm{GPa}$ and $690{ }^{\circ} \mathrm{C}$, However, this result may be unreliable because of probable cation transfer between the outer rim and the matrix at lower temperatures. On the other hand, the outer rims of porphyroblasts in LB09-9.3 yielded 2.05 $\mathrm{GPa}$ and $547{ }^{\circ} \mathrm{C}$ using the garnetclinopyroxene-kyanite- $\mathrm{SiO}_{2}$ net-transfer thermometer that is less susceptible to later thermal re-equilibration (Ravna and Terry 2004). Since such re-equilibration cannot be completely ruled out, we consider $547^{\circ} \mathrm{C}$ as the minimum temperature for the rims. Thus, the rims formed at temperatures at least $\sim 70{ }^{\circ} \mathrm{C}$ higher than the core with a slight decrease in pressure ( $\sim 0.2 \mathrm{GPa})$. The core-rim temperature difference was probably higher if lower temperature re-equilibration is taken into account.

The $P-T$ conditions of the core-rim interface region of garnet in LB09-8.1 can be constrained from the compositions of the garnet outer core and inner rim, and the omphacite inclusion at the interface (Fig. 5b). To minimize the effect of lower temperature re-equilibration on the estimated temperatures, the composition at the center of the $100 \mu \mathrm{m}$-sized omphacite inclusion was considered in the calculations. Core compositions of such grains cooling at moderate rates from peak temperatures of $\sim 700{ }^{\circ} \mathrm{C}$ are not expected to change significantly (cf. Müller et al. 2013). The calculations indicate that the outer core equilibrated at $2.41 \mathrm{GPa}$ and $484{ }^{\circ} \mathrm{C}$, and the inner rim equilibrated at 2.31 GPa and $627{ }^{\circ} \mathrm{C}$ (Fig. 7). Because some lower temperature re-equilibration is possible, these temperatures should be considered as minimum. Thus, there is a sharp increase in the equilibrium temperature from $\sim 484{ }^{\circ} \mathrm{C}$ to $\geq 627{ }^{\circ} \mathrm{C}$ across the core-rim interface of garnet. 


\section{P-T pseudosection analysis}

The $P$-T paths of metamorphism were additionally determined through $P-T$ and $T-\mathrm{M}_{\mathrm{CO} 2}$ pseudosections calculated using fractionation-corrected, effective bulk compositions (Figs. 8-13) in the $\mathrm{K}_{2} \mathrm{O}-\mathrm{Na}_{2} \mathrm{O}-\mathrm{CaO}-\mathrm{FeO}-\mathrm{MgO}-\mathrm{Al}_{2} \mathrm{O}_{3}-\mathrm{SiO}_{2}-\mathrm{TiO}_{2}-\mathrm{H}_{2} \mathrm{O}-\mathrm{O}-\mathrm{C}$ (KNCFMASTHOc) system. The importance of using fractionation-corrected bulk compositions in determining the $P-T$ path has been demonstrated by Konrad-Schmolke et al. (2008). The calculations were performed with the Perple_X Version 6.6.6 software (Connolly and Petrini 2002) using the updated internally consistent thermodynamic database (Holland and Powell 1998), the solution models for garnet (White et al. 2007), omphacitic clinopyroxene (Green et al. 2007), clinoamphibole (Diener et al. 2007), phengitic mica (Coggon and Holland 2002, Auzanneau et al. 2010), biotite (Powell and Holland 1999), epidote (Holland and Powell 1998), chlorite (Holland et al. 1998), plagioclase (Newton et al. 1980), and melt (Holland and Powell 2001, White et al. 2001), and the equation of state for $\mathrm{H}_{2} \mathrm{O}-\mathrm{CO}_{2}$ fluids (Holland and Powell 1991, 1998).

\section{Bulk compositions}

Three distinct mineral assemblages can be identified in the eclogites (Table 3) from textural relations (Figs. 4-6) as discussed below. The early assemblages designated as 8.1A (in LB09-8.1) and 9.3A (in LB09-9.3) include the Ca-Fe-rich garnet cores and the omphacite cores. Other phases such as zoisite, amphibole, Si-rich phengite and carbonates were probably part of the early assemblage. However, the proportions of the phases cannot be evaluated because they have been chemically re-equilibrated through open system processes during exhumation. On the other hand, the inclusions within the 
garnet core and the surrounding contact zone of the host garnet may represent a retrogressed version of the original early assemblage assuming that the original assemblage was metamorphosed within a closed system during the exhumation. Such an assumption may not be correct because eclogitic garnets are known to form atoll structures where the high- $P$ cores become unstable during exhumation and are replaced by lower pressure minerals through open system processes (Cheng et al. 2007, St-Onge et al. 2013). We calculated the bulk compositions of the early assemblages using the mineral compositions and modes of the inclusions within the garnet core (9.3A) in addition to the contact zone of the host garnet surrounding the inclusions (8.1 A, Table 3$)$. However, we note that the bulk compositions of the early assemblages are not wellconstrained because we cannot rule out the presence of atoll garnet in these samples.

The second assemblage consists of the thick Mg-rich garnet rims, omphacite rims and the matrix phases (8.1B and 9.3B). This assemblage is the major constituent of the studied samples, and its bulk compositions calculated using mineral compositions and modes are relatively well constrained (Table 3 ). The calculated bulk compositions of both the early and intermediate assemblages resemble $\mathrm{H}_{2} \mathrm{O}$ - and $\mathrm{CO}_{2}$-rich high-Ti tholeiitic basalts with 45-48 wt $\% \mathrm{SiO}_{2}, 0.6-1.3 \mathrm{wt} \% \mathrm{H}_{2} \mathrm{O}$ and up to $6.5 \mathrm{wt} \% \mathrm{CO}_{2}$ (Table 3).

The third (late-stage) assemblage includes thin reaction rinds and fine-grained intergrowths surrounding the garnet and omphacite porphyroblasts (8.1C and 9.3C). The bulk compositions of these assemblages calculated using their corresponding mode and mineral compositions are andesitic (53-60 wt $\% \mathrm{SiO}_{2}$, Table 3). These bulk compositions are markedly different from the tholeiitic compositions of the early and intermediate 
assemblages. This is because the bulk compositions of $8.1 \mathrm{C}$ and $9.3 \mathrm{C}$ are for small domains of minor volume within the samples containing only late-stage minerals.

\section{Early metamorphic stage A}

The calculated $P-T$ pseudosection for 8.1A (Fig. 8) shows that the analyzed omphacite cores $\left(\mathrm{Aug}_{>50} \mathrm{Jd}_{>45}\right)$ in sample LB09-8.1 are stable along with epidote, mica, ilmenite, rutile, quartz and carbonates at 2.2-2.3 $\mathrm{GPa}$ and $400-425{ }^{\circ} \mathrm{C}$. For sample LB09-9.3, the center of the analyzed garnet core $\left(\operatorname{Prp}_{<20} \mathrm{Grs}>_{30}\right.$, Fig. 6) also plots approximately at 2.22.3 $\mathrm{GPa} / 400{ }^{\circ} \mathrm{C}$ in an assemblage field that contains omphacite, amphibole, epidote, mica, ilmenite, rutile, kyanite and quartz (pseudosection for 9.3A, Fig. 9a,b). The calculated assemblages also include lawsonite in LB09-8.1, and talc and chlorite in LB09-9.3. These phases presumably have not survived the intermediate heating stage (see below) and have been replaced by phases such as epidote/zoisite, amphiboles and quartz during the later stages. Interestingly, although these $P-T$ results are based on poorly constrained bulk compositions, they are closely similar to the $P$ - $T$ conditions of 2.2-2.5 $\mathrm{GPa}$ and $458-480{ }^{\circ} \mathrm{C}$ for the porphyroblast cores obtained from thermobarometry.

Furthermore, the observed compositional variation in the garnet core of LB09-9.3 (Fig. 6) matches the calculated variation between $\sim 2.2 \mathrm{GPa} / 400{ }^{\circ} \mathrm{C}$ and $\sim 1.8 \mathrm{GPa} / 650{ }^{\circ} \mathrm{C}$ (Fig. 9b), and the analyzed garnet core $\left(\operatorname{Prp}_{>_{6}} \mathrm{Grs}_{<33}\right.$, Fig. 5) in LB09-8.1 also equilibrated along this same general $P-T$ trajectory $\left(\sim 1.6-1.9 \mathrm{GPa},>550{ }^{\circ} \mathrm{C}\right.$, Fig. 8$)$. Thus, the $P-T$ path between $2.2-2.3 \mathrm{GPa} / 400-425{ }^{\circ} \mathrm{C}$ and $\sim 1.8 \mathrm{GPa} / 650{ }^{\circ} \mathrm{C}$ characterizes the early metamorphic conditions for $8.1 \mathrm{~A}$ and $9.3 \mathrm{~A}$, and indicates a heating trend with a decrease in pressure. Two hypothetical $P-T$ paths, one showing isobaric heating followed by 
isothermal decompression (Path I) and the other showing isothermal decompression followed by isobaric heating (Path II), fail to reproduce the garnet core compositions (Grs and Prp for Path I, and Grs for Path II, Fig. 9b,c).

\section{Intermediate metamorphic stage $B$}

The calculated pyrope and grossular compositional isopleths matching the analyzed Mgrich garnet outer rim $\left(\operatorname{Prp}_{24.5-25.5} \mathrm{Grs}_{25.5-26.0}\right.$, Fig. 5) in sample LB09-8.1 approach but do not intersect at $\sim 1.6 \mathrm{GPa} / 720{ }^{\circ} \mathrm{C}$ in the pseudosection for $8.1 \mathrm{~B}$ (Fig. 10). However, a $T$ $\mathrm{M}_{\mathrm{CO} 2}$ pseudosection at $1.8 \mathrm{GPa}$ for $8.1 \mathrm{~B}$ shows that the relevant isopleths intersect between $670{ }^{\circ} \mathrm{C}$ and $690{ }^{\circ} \mathrm{C}$ with a slightly lower $\left(\sim 5\right.$ mole \%) $\mathrm{CO}_{2}$ (Fig. 11) than estimated for 8.1B $(\sim 7$ mole $\%)$, and the calculated assemblage contains garnet, omphacite, mica, zoisite, rutile, quartz, carbonates and a small amount of melt. Furthermore, for sample LB09-9.3, the isopleths matching the garnet outer rim $\left(\operatorname{Prp}_{{ }_{30}} \mathrm{Grs}_{<17}\right.$, Fig. 6) intersect at $\sim 1.8-1.9 \mathrm{GPa}$ and $\sim 690-720{ }^{\circ} \mathrm{C}$ in an assemblage field that also contains omphacite, mica, kyanite, rutile, quartz, carbonates and minor melt (pseudosection for 9.3B, Fig. 12). All the minerals in the calculated assemblages in these pseudosections (Figs. 10-12) are observed in the samples. Amphibole observed in the samples was probably stabilized at lower pressures as indicated by the pseudosections. Notably, plagioclase is absent both in the observed and calculated assemblages - the pseudosections show that plagioclase is stable below $1.6-1.7 \mathrm{GPa}$ at $675-750{ }^{\circ} \mathrm{C}-$ indicating that the intermediate assemblages equilibrated at pressures $>1.6 \mathrm{GPa}$. We thus conclude that the carbonate-rich $8.1 \mathrm{~B}$ and $9.3 \mathrm{~B}$ assemblages equilibrated at $1.8-1.9 \mathrm{GPa}$ and $\sim 670-720{ }^{\circ} \mathrm{C}$ during the intermediate stage of metamorphism. In $P-T$ space, these $P-T$ 
conditions approximately plot on an extension of the $P-T$ path for the early metamorphic stage along the same direction. Thus, the early to intermediate $P-T$ path of metamorphism is characterized by heating (from $\sim 425{ }^{\circ} \mathrm{C}$ to $\sim 720{ }^{\circ} \mathrm{C}$ ) accompanied by decompression (from $\sim 2.3$ to $\sim 1.8 \mathrm{GPa}$ ). This result is consistent with the $\sim 484{ }^{\circ} \mathrm{C}$ to $\geq 640{ }^{\circ} \mathrm{C}$ temperature increase at 2.4-2.3 GPa pressures calculated across the core-rim interface of garnet from thermobarometry.

In the $P-T$ pseudosections for the $8.1 \mathrm{~B}$ and $9.3 \mathrm{~B}$ (Figs. 10 and 12), we have used the melt solution model in the calculations. Although the melt solution model was devised for pelitic bulk compositions, we have used it to avoid high- $T$ metastable equilibria. Because of the possibility of melting at high- $T\left(>715^{\circ} \mathrm{C}\right.$ at c. $\left.1.6-1.7 \mathrm{GPa}\right)$, pseudosections computed without considering the melt model may lead to metastable equilibria in eclogites (Štípská and Powell 2005). Our calculations for 8.1B show that there is only incipient melting at these $P-T$ conditions, and the equilibrium $T$ increases by $\sim 10{ }^{\circ} \mathrm{C}$ at the same pressure when the melt model is not used. This temperature difference is within the uncertainties of the estimated temperature range for the intermediate metamorphic stage.

\section{Late metamorphic stage $C$}

The pseudosections for $8.1 \mathrm{C}$ and $9.3 \mathrm{C}$ constrain the $P-T$ conditions of the late metamorphic stage (Fig. 13). The analyzed actinolite (Mg\# 77) and augite (Aug 88 ) are stable along with albite at $\sim 0.8 \mathrm{GPa} / 605-620^{\circ} \mathrm{C}$ for $8.1 \mathrm{C}$ (Fig. 13a), and the analyzed biotite (Mg\# 62) and plagioclase $\left(\mathrm{An}_{23}\right)$ are stable along with amphibole and phengitic mica at $0.40-0.45 \mathrm{GPa} / 450-470{ }^{\circ} \mathrm{C}$ for $9.3 \mathrm{C}$ (Fig. 13b). Thus the late assemblages 
crystallized between the $P-T$ conditions of $\sim 0.8 \mathrm{GPa} / 605-620{ }^{\circ} \mathrm{C}$ and $0.40-0.45 \mathrm{GPa} / 450-$ $470{ }^{\circ} \mathrm{C}$.

\section{Discussion}

Our $P$ - $T$ results from thermobarometry are based on the presence of the garnet + clinopyroxene + phengite \pm kyanite $+\mathrm{SiO}_{2}$ assemblage, and are independent of the bulk compositions of the samples. On the other hand, the results based on pseudosections depend on the choice of bulk compositions, and these are not well-constrained for stage A. Also, our interpretations of the pseudosections are primarily based on a comparison of the observed compositional variations in the minerals and the calculated mineral composition isopleths. Although the calculated assemblages broadly resemble the observed assemblages, we have not attempted to match them because the original assemblages have been modified through heating, decompression and cooling during the exhumation of the eclogite. Preservation of the early appearing phases such as lawsonite and chlorite is unlikely because eclogites transit through large pressure and temperature gradients during their exhumation. In spite of these uncertainties in our pseudosection approach, both the thermobarometry and the pseudosection analysis methods indicate that the garnet inner cores formed at $\sim 2.2-2.5 \mathrm{GPa}$ and $\sim 400-480{ }^{\circ} \mathrm{C}$, and there is a core-torim heating trend with a modest decrease in pressure (Figs. 7, 14a).

As mentioned earlier, the $P-T$ results for the garnet rims may depend on their composition in the studied sample; St-Onge et al. (2013) obtained $\sim 2.7 \mathrm{GPa}$ and $\sim 640{ }^{\circ} \mathrm{C}$, whereas de Sigoyer et al. (1997) obtained $1.1 \mathrm{GPa}$ and $580{ }^{\circ} \mathrm{C}$. Our estimated pressures of 1.8-1.9 GPa are intermediate between the pressures in the two above studies, whereas our 
temperature estimates of $670-720{ }^{\circ} \mathrm{C}$ are higher. Our garnet rim zoning patterns are significantly different from those in St-Onge et al. (2013). Our garnet grains show a sharp decrease in grossular and a sharp increase in pyrope at the core-rim boundary (e.g. LB098.1, Fig. 5), similar to a garnet grain analyzed by Konrad-Schmolke et al. (2008, their Fig. $2 b$, profile 2). Within the rim, grossular increases gradually to Grs $\cos _{25}$ in the outer rim. Pyrope decreases up to the mid-rim, but increases to $\operatorname{Prp}_{\sim 25}$ in the outer rim. In contrast, the garnet rim profile in St-Onge et al. (2013) shows continuity with the core profile. Grossular decreases gradually to mid-rim and levels off at Grs $\sim 19$ in the outer rim. Pyrope is somewhat constant in the inner rim but increases gradually to $\operatorname{Prp}_{>33}$ in the outer rim. Thus, compared to the garnet outer rim in this study $\left(\mathrm{Grs}_{\sim 25} \operatorname{Prp}_{\sim 25}\right)$, the garnet outer rim in St-Onge et al. (2013) has a lower grossular content and a much higher pyrope content.

To consider the effect of bulk composition on our $P-T$ estimates from pseudosection analysis, we plotted our garnet compositions on the pseudosection computed by St-Onge et al. (2013, their Fig. 11). The garnet core of LB09-8.1 plots at 2 $\mathrm{GPa}$ and $520{ }^{\circ} \mathrm{C}$, whereas the rim plots at two $P-T$ values of $2.3 \mathrm{GPa} / 620{ }^{\circ} \mathrm{C}$ and 1.8 $\mathrm{GPa} / 675{ }^{\circ} \mathrm{C}$ on their diagram (see Fig. $14 \mathrm{a}$ ). The dual solution for the rim is probably due to the effect of bulk composition. With our relatively well-constrained bulk compositions for stage $\mathrm{B}(8.1 \mathrm{~B}$ and $9.3 \mathrm{~B})$, we obtain only one $P-T$ result that is similar to the lower pressure solution. Interestingly however, the $2 \mathrm{GPa} / 520{ }^{\circ} \mathrm{C}$ (core) and $1.8 \mathrm{GPa} / 675{ }^{\circ} \mathrm{C}$ (rim) points are fully consistent with the $P-T$ path obtained from our pseudosection analysis. Thus, the observed core-to-rim temperature increase seems to be a robust result and independent of the chosen bulk composition. Based on our results from 
thermobarometry (with one exception) and pseudosection analysis, as well as comparing our garnet compositions with the pseudosection in St-Onge et al. (2013), we prefer a model of heating from $\sim 425{ }^{\circ} \mathrm{C}$ to $\sim 720{ }^{\circ} \mathrm{C}$ as the pressure decreased from $\sim 2.3 \mathrm{GPa}$ to $\sim 1.8 \mathrm{GPa}$ during metamorphism from stage A to stage B (Fig. 14a). The only exception is the $2.7 \mathrm{GPa}$ and $690{ }^{\circ} \mathrm{C}$ thermobarometric result for the outer rims in LB09-8.1. This result is similar to the $P-T$ of rim determined by St-Onge et al. (2013), but it is unreliable as it may be compromised due to cation transfer at lower $P-T$ and is not supported by our pseudosection results for stage B.

Our $P-T$ path of metamorphism for the Tso Morari eclogite has some differences with the paths in all of the previous studies (Figs. 2, 14a). The pseudosection for 8.1A shows that the highest Si contents in phengite are in the high- $P /$ low- $T$ part of the diagram (Fig. 8d), and we see no evidence for $>4 \mathrm{GPa}$ pressures on the basis of Si content of phengite as calculated for a talc-kyanite-coesite bearing assemblage by Mukherjee et al. (2003). Such ultrahigh pressures remain unconfirmed because diamond has not been observed in the Tso Morari eclogite (cf. Mukherjee and Sachan 2004). Compared to the results of St-Onge et al. (2013), it is noteworthy that our $P$ - $T$ estimates for stage B overlap with their $P$-T path between $2.7 \mathrm{GPa}$ and $1.25 \mathrm{GPa}$, and our stage B temperature overlaps with their garnet equilibration temperature of $690 \pm 25^{\circ} \mathrm{C}$ for the Puga gneiss (Fig. 14a). Our $P-T$ path below $0.8 \mathrm{GPa}$ is also similar to those shown in de Sigoyer et al. (1997), Guillot et al. (1997) and Mukherjee et al. (2003) (Fig. 14a). But we do not see a Barrovian overprint on the eclogitic textures. This is possibly because the UHP eclogites in this study cooled from a higher temperature than the highest temperature attained during the Barrovian metamorphism. 
Time interval for the intermediate heating stage

We have used the Ca zonation in garnet showing a sharp concentration decrease across the core-rim interface to calculate the time interval for the intermediate heating stage. We calculated the residence times for the eclogites at high temperature to retain the earlier formed $\mathrm{Ca}$ concentration profile across the core-rim interface without significant flattening using the formulations for effective diffusion coefficient of $\mathrm{Ca}$ in $\mathrm{Ca}-\mathrm{Mg}-\mathrm{Fe}$ garnet (Chakraborty and Ganguly 1992), constants for self-diffusion coefficients of Ca, Fe and Mg in garnet based on experimental data (Ganguly et al. 1998), and the equation for elemental diffusion (Crank 1975). The results for the compositional profiles of the four garnet grains shown in Figs. 5 and 6 on both sides of the core were averaged to calculate the residence times. The calculations indicate that heating during the intermediate stage was a short transient event that lasted only 0.03-0.09 Myr. Longer residence times at high temperatures would lead to diffusional re-equilibration and flattening of the step-like compositional profile across the core-rim boundary. These results are in line with the fast $(>12 \mathrm{~mm} / \mathrm{yr}$ for Tso Morari; St-Onge et al. 2013) and extremely fast (30-143 mm/yr for Kaghan, Kaneko et al. 2003, Parrish et al. 2006, Wilke et al. 2010) exhumation rates estimated for the northwestern Himalayan eclogites.

\section{Exhumation model}

In Figure 14a, we compare the $P-T$ path of metamorphism of the Tso Morari eclogite from this and other studies with thermal models of the globally active subduction zones (Syracuse et al. 2010). All existing $P-T$ constraints for the Tso Morari eclogitic rocks are at odds with the classical model of exhumation through the subduction channel (cf. Cloos 
and Shreve 1988, Guillot et al. 2001, Gerya et al. 2002), or as a part of a developing collisional orogen (purple shaded region, Faccenda et al. 2008). The initial $P-T$ conditions of $\sim 2.3 \mathrm{GPa}$ and $400-425{ }^{\circ} \mathrm{C}$ (Stage A) are consistent with the thermal conditions inferred for slab surfaces and indicate that UHP metamorphism occurred in the subducting slab. In contrast, the $\sim 1.8 \mathrm{GPa} / 700{ }^{\circ} \mathrm{C}$ conditions of the intermediate stage (Stage $\mathrm{B}$ ) are higher in temperature than the surface temperatures of even the hottest (shallowest) slab at the same pressure. Interestingly, although the paths from previous studies cover a wide range of $P$ - $T$ conditions, the $<2 \mathrm{GPa}$ results for isothermal decompression also plot in the higher temperature side of the surface conditions for the hottest slab (Fig. 14a). Recent numerical simulations and geochemical and petrological modeling (Gerya et al. 2004, Behn et al. 2011, Hacker et al. 2011) have demonstrated the feasibility of diapirs of low density crustal rocks rising from the subducting slab through the mantle wedge, and the $P-T$ path in this study is similar to the numerically simulated lower temperature $P-T$ paths of translithopheric diapirs ascending through the mantle wedge (light red shaded region, Vogt et al. 2013). Hacker and Gerya (2013) have reviewed the expected geological characteristics of UHP terranes exhumed by different exhumation mechanisms (see their Table 1). Trans-mantle diapirs of 10-20 km radius are characterized by rapid ascent, and a radially symmetric dome structure without a basal fault. The Tso Morari dome matches these features remarkably well. We thus conclude that the Tso Morari eclogite was possibly exhumed through the mantle wedge (Fig. 14b). The temperatures recorded due to transient heating within the mantle wedge may be lower than the temperature of the surrounding mantle through which the diapir ascended. Furthermore, the temperatures within the different parts of the diapir may be different because of differential heating 
from different directions, though internal convection may tend to homogenize the temperature differences. We consider it possible that the wide range of temperatures recorded at intermediate pressures in the Tso Morari eclogite as found in this and previous studies reflect variable re-equilibration of the high-pressure metamorphic assemblages due to transient heating during exhumation through the mantle wedge.

The calculated densities of the Tso Morari ortho- and para-gneisses are 100-300 $\mathrm{kg} / \mathrm{m}^{3}$ less than mantle wedge peridotites at $\sim 2.5 \mathrm{GPa}$. If we assume that the Tso Morari dome is a $2 \mathrm{~km}$-thick flattened diapir of $40-60 \mathrm{~km}$ diameter (average size of the exposed dome), a density difference of $200 \mathrm{~kg} / \mathrm{m}^{3}$, and low mantle viscosities between $1.7 \times 10^{19}$ and 5.0x10 19 Pa.s (cf. Billen and Gurnis 2001), we can estimate the terminal Stokes velocities of ascent of an originally spherical diapir of the same volume (17-22 km diameter) as $29-147 \mathrm{~mm} / \mathrm{yr}$, which is comparable to the exhumation rates of Kaghan UHP rocks in northern Himalaya (cf. Parrish et al. 2006, Wilke et al. 2010). Accordingly, the diapir would require $0.4-1.8 \mathrm{Myr}$ to rise from $83 \mathrm{~km}$ to $30 \mathrm{~km}$ depths (2.5 GPa to 0.5 GPa). In the absence of precise geochronological data for the different metamorphic stages in our samples, the first order exhumation rates for the Tso Morari eclogites calculated above should be considered as averages. However, it is likely that exhumation from stage A to stage B was very fast, so that a gradual compositional change could not develop between the core and rim of garnet during formation of the rim. As mentioned above, the residence time of the diapir within the hot region of the mantle wedge was very short (0.03-0.09 Myr), otherwise the step-like compositional profile across the corerim boundary would have been efficiently flattened by cation diffusion at high temperatures. Hence, the time interval for exhumation from stage B to stage C was 
probably the longest. The exhumation of the Tso Morari eclogites probably started shortly after the Indian plate collided with the so-called Kohistan-Ladakh island arc at $50.1 \pm 1.5 \mathrm{Ma}$ (cf. Zhu et al. 2005), and geochronological data in de Sigoyer et al. (2000) suggest that they had reached amphibolite facies conditions of $\sim 0.9 \mathrm{GPa}$ by ca. $47 \mathrm{Ma}$ and upper crustal conditions of $<0.5 \mathrm{GPa}$ by ca. $30 \mathrm{Ma}$. Thus, our conclusions regarding the exhumation rates are consistent with the available geochronological data.

We thus propose that ascent of $\mathrm{UH} P$ rocks as diapir through the mantle wedge is a viable mechanism to explain their fast exhumation in accordance with the exhumation mechanism proposed for the UHP rocks of Papua New Guniea (Little et al. 2011). We conclude that the Tso Morari eclogites represent the remnants of a diapir that originated in the subducting slab after UHP metamorphism and likely ascended through the overlying mantle wedge thereby recording a short-lived transient heating event (Fig. 14b). The Tso Morari diapir impinged under the lower crust of the overriding plate in early Eocene and was subsequently incorporated within the Himalayan nappe stack. This model explains the presence of ophiolite remnants all around the Tso Morari dome, especially at its southwestern periphery (Fig. 1).

Acknowledgements We gratefully acknowledge the constructive and detailed comments from two anonymous reviewers during peer review that helped in improving the presentation of the manuscript. Constructive comments from Richard Palin, Dave Waters, and Weronika Gorczyk on an earlier version are also gratefully appreciated. We also thank Tim Grove and Leigh Royden for helpful discussions regarding the exhumation model. Partial funding for this work was provided by NSF EAR 0910644 to O.J. 


\section{References}

Armbruster T, Bonazzi P, Akasaka M, Bermanec V, Chopin C, Giere R, HeussAssbichler S, Liebscher A, Menchetti S, Pan Y, Pasero M (2006) Recommended nomenclature of epidote-group minerals. Eur J Mineral 18:551-567 doi: $10.1127 / 0935-1221 / 2006 / 0018-0551$

Armstrong JT (1995) CITZAF - A package for correction programs for the quantitative electron microbeam x-ray analysis of thick polished materials, thin-films and particles. Microbeam Anal 4:177-200

Auzanneau E, Schmidt MW, Vielzeuf D, Connolly JAD (2010) Titanium in phengite: a geobarometer for high temperature eclogites. Contrib Mineral Petrol 159:1-24 doi: $10.1007 / \mathrm{s} 00410-009-0412-7$

Behn MD, Kelemen PB, Hirth G, Hacker BR, Massonne H-J (2011) Diapirs as the source of the sediment signature in arc lavas. Nature Geosci 4:641-646 doi: $10.1038 /$ ngeo 1214

Berthelsen A (1953) On the geology of the Rupshu District, N.W. Himalaya: Medd Dansk Geol Foren 12:350-415 http://2dgf.dk/xpdf/bull-1953-12-3-350-414.pdf

Billen MI, Gurnis M (2001) A low viscosity wedge in subduction zones. Earth Planet Sci Lett 193:227-236 doi: 10.1016/S0012-821X(01)00482-4 
Bohlen SR, Boettcher AL (1982) The quartz-coesite transformation: a precise determination and the effects of other components. J Geophys Res 87:7073-7078 doi: 10.1029/JB087iB08p07073

Bouilhol P, Jagoutz O, Hanchar JM, Dudas FO (2013) Dating the India-Eurasia collision through arc magmatic records. Earth Planet Sci Lett 366:163-175 doi: 10.1016/j.epsl.2013.01.023

Bundy FP (1980) The $P$-T phase and reaction diagram for elemental carbon. J Geophys Res 85:6930-6936 doi: 10.1029/JB085iB12p06930

Chakraborty S, Ganguly J (1992) Cation diffusion in aluminosilicate garnets experimental determination in spressartine-almandine diffusion couples, evaluation of effective binary diffusion coefficients, and applications. Contrib Mineral Petrol 111:74-86 doi: 10.1007/BF00296579

Cheng H, Nakamura E, Kobayashi K, Zhou Z (2007) Origin of atoll garnets in eclogites and implications for the redistribution of trace elements during slab exhumation in a continental subduction zone. Amer Mineral 92:1119-1129 doi: $10.2138 / \mathrm{am} .2007 .2343$

Cloos M, Shreve RL (1988) Subduction-channel model of prism accretion, mélange formation, sediment subduction, and subduction erosion at convergent plate margins: 2. Implications and discussion. Pure Appl Geophys 128:501-545 doi: 10.1007/BF00874549 
Coggon R, Holland TJB (2002) Mixing properties of phengitic micas and revised garnetphengite thermobarometers. J Metamorph Geol 20:683-696 doi: 10.1046/j.15251314.2002.00395.x

Connolly JAD, Petrini K (2002) An automated strategy for calculation of phase diagram sections and retrieval of rock properties as a function of physical conditions. $\mathrm{J}$ Metamorph Geol 20:697-708 doi: 10.1046/j.1525-1314.2002.00398.x

Crank J (1975) The mathematics of diffusion. Oxford, Oxford University Press, 414 p.

Diener JFA, Powell R, White RW, Holland TJB (2007) A new thermodynamic model for clino-and orthoamphiboles in the system $\mathrm{Na}_{2} \mathrm{O}-\mathrm{CaO}-\mathrm{FeO}-\mathrm{MgO}-\mathrm{Al}_{2} \mathrm{O}_{3}-\mathrm{SiO}_{2}-\mathrm{H}_{2} \mathrm{O}-\mathrm{O}$. J Metamorph Geol 25:631-656 doi: 10.1111/j.1525-1314.2007.00720.x

de Sigoyer J, Guillot S, Lardeaux JM, Mascle G (1997) Glaucophane-bearing eclogites in the Tso Morari dome (eastern Ladakh, NW Himalaya). Eur J Mineral 9:1073-1083 http://eurjmin.geoscienceworld.org/content/9/5/1073.full.pdf

de Sigoyer J, Chavagnac V, Blichert-Toft J, Villa IM, Luais B, Guillot S, Cosca M, Mascle G (2000) Dating the Indian continental subduction and collisional thickening in the northwest Himalaya: multichronology of the Tso Morari eclogites. Geology 28:487-490 doi: 10.1130/0091-7613

de Sigoyer J, Guillot S, Dick P (2004) Exhumation of the ultrahigh-pressure Tso Morari unit in eastern Ladakh (NW Himalaya): a case study. Tectonics 23:TC3003 doi: $10.1029 / 2002$ TC001492 
Donaldson DG, Webb AAG, Menold CA, Kylander-Clark ARC, Hacker BR (2013) Petrochronology of Himalayan ultrahigh-pressure eclogite. Geology 41:835-838 doi: $10.1130 / \mathrm{G} 33699.1$

Epard J-L, Steck A (2008) Structural development of the Tso Morari ultra-high pressure nappe of the Ladakh Himalaya. Tectonophysics 451:242-264 doi: 10.1016/j.tecto.2007.11.050

Faccenda M, Gerya TV, Chakraborty S (2008) Styles of post-subduction collisional orogeny: influence of convergence velocity, crustal rheology and radiogenic heat production. Lithos 103:257-287 doi: 10.1016/j.lithos.2007.09.009

Ganguly J, Cheng WJ, Chakraborty S (1998) Cation diffusion in aluminosilicate garnets: experimental determination in pyrope-almandine diffusion couples. Contrib Mineral Petrol 131:171-180 doi: 10.1007/s004100050386

Gerya TV, Stöckhert B, Perchuk AL (2002) Exhumation of high-pressure metamorphic rocks in a subduction channel: A numerical simulation. Tectonics 21(6):1056 doi:10.1029/2002TC001406

Gerya TV, Yuen DA, Sevre EOD (2004) Dynamical causes for incipient magma chambers above slabs. Geology 32:89-92 doi: 10.1130/G20018.1

Green ECR, Holland TJB, Powell R (2007) An order-disorder model for omphacitic pyroxenes in the system jadeite-diopside-hedenbergite-acmite, with applications to eclogite rocks. Amer Mineral 92:1181-1189 doi: 10.2138/am.2007.2401 
Guillot S, de Sigoyer J, Lardeaux JM, Mascle G (1997) Eclogitic metasediments from the Tso Morari area (Ladakh Himalaya): Evidence for continental subduction during India-Asia convergence. Contrib Mineral Petrol 128:197-212 doi: $10.1007 / \mathrm{s} 004100050303$

Guillot S, Hattori KH, de Sigoyer J, Nägler T, Auzende A-L (2001) Evidence of hydration of the mantle wedge and its role in the exhumation of eclogites. Earth Planet Sci Lett 193:115-127 doi: 10.1016/S0012-821X(01)00490-3

Hacker B, Gerya T (2013) Paradigms, new and old, for ultrahigh-pressure tectonism. Tectonophysics 603:79-88 doi: 10.1016/j.tecto.2013.05.026

Hacker BR, Kelemen PB, Behn MD (2011) Differentiation of the continental crust by relamination. Earth Planet Sci Lett 307:501-516 doi:10.1016/j.eps1.2011.05.024

Holland TJB, Powell R (1991) A compensated Redlich-Kwong (CORK) equation for volumes and fugacities of carbon dioxide and water in the range 1 bar to $50 \mathrm{kbar}$ and 100-1600 ${ }^{\circ}$ C. Contrib Mineral Petrol 109:265-273 doi: 10.1007/BF00306484

Holland TJB, Powell R (1998) An internally consistent thermodynamic data set for phases of petrological interest. J Metamorph Geol 16:309-343 doi: 10.1111/j.15251314.1998.00140.x

Holland TJB, Powell R (2001) Calculation of phase relations involving haplogranitic melts using an internally consistent thermodynamic dataset. J Petrol 42/4:673-683 doi: $10.1093 /$ petrology/42.4.673 
Holland TJB, Barker J, Powell R (1998) Mixing properties and activity-composition relationships of chlorites in the system $\mathrm{MgO}-\mathrm{FeO}-\mathrm{Al}_{2} \mathrm{O}_{3}-\mathrm{SiO}_{2}-\mathrm{H}_{2} \mathrm{O}$. Eur $\mathrm{J}$ Mineral 10:395-406 http://eurjmin.geoscienceworld.org/content/10/3/395.full.pdf

Kaneko Y, Katayama I, Yamamoto H, Misawa K, Ishikawa M, Rehman HU, Kausar AB, Shiraishi K (2003) Timing of Himalayan ultrahigh-pressure metamorphism: sinking rate and subduction angle of the Indian continental crust beneath Asia. J Metamorph Geol 21:589-599 doi: 10.1046/j.1525-1314.2003.00466.x

Konrad-Schmolke M, O'Brien PJ, de Capitani C, Carswell DA (2008) Garnet growth at high- and ultra-high pressure conditions and the effect of element fractionation on mineral modes and composition. Lithos 103:309-332 doi:10.1016/j.lithos.2007.10.007

Leech ML, Singh TS, Jain AK, Klemperer SL, Manickavasagam RM (2005) The onset of India-Asia continental collision: Early, steep subduction required by the timing of UHP metamorphism in the western Himalaya. Earth Planet Sci Lett 234:83-97 doi:10.1016/j.epsl.2005.02.038

Leake B, Woolley AR, Arps CES, Birch WD, Gilbert MC, Grice JD, Hawthorne FC, Kato A, Kisch H, Krivovichev VG, Linthout K, Laird J, Mandarino JA, Maresch WV, Nickel EH, Rock NMS, Schumacher JC, Smith DC, Stephenson NCN, Ungaretti L, Whittaker EJW, Yoizhi G (1997) Nomenclature of amphiboles: report of the subcommittee on amphiboles of the International Mineralogical Association, 
Commission on new minerals and mineral names. Can Mineral 35:219-246 http://canmin.geoscienceworld.org/content/35/1/219.full.pdf

Little TA, Hacker BR, Gordon SM, Baldwin SL, Fitzgerald PG, Ellis S, Korchinski M (2011) Diapiric exhumation of Earth's youngest (UHP) eclogites in the gneiss domes of the D'Entrecasteaux Islands, Papua New Guinea. Tectonophysics 510:39-68 doi: 10.1016/j.tecto.2011.06.006

Mahéo G, Bertrand H, Guillot S, Villa IM, Keller F, Capiez P (2004) The South Ladakh ophiolites (NW Himalaya, India): an intra-oceanic tholeiitic arc origin with implication for the closure of the Neo-Tethys. Chem Geol 203:273-303 doi: 10.1016/j.chemgeo.2003.10.007

Morimoto N, Fabries J, Ferguson AK, Ginzburg IV, Ross M, Seifert FA, Zussman L, Aoki K, Gottardi G (1988) Nomenclature of pyroxenes. Mineral Mag 52:535-550 doi: 10.1180/minmag.1988.052.367.15

Mukherjee BK, Sachan HK (2004) Garnet response diamond pressure metamorphism from Tso Morari region, Ladakh, India. Himalayan J Sci 2:209 http://www.nepjol.info/index.php/HJS/article/download/902/899

Mukherjee BK, Sachan HK, Ogasawara Y, Muko A, Yoshioka N (2003) CarbonateBearing UHPM Rocks from the Tso Morari Region, Ladakh, India: petrological implications. Intern Geol Rev 45:49-69 doi: 10.2747/0020-6814.45.1.49 
Müller T, Dohmen R, Becker HW, ter Heege JH, Chakraborty S (2013) Fe-Mg interdiffusion rates in clinopyroxene: experimental data and implications for $\mathrm{Fe}-\mathrm{Mg}$ exchange geothermometers. Contrib Mineral Petrol 166:1563-1576 doi: $10.1007 / \mathrm{s} 00410-013-0941-\mathrm{y}$

Newton RC, Charlu TV, Kleppa OJ (1980) Thermochemistry of the high structural state plagioclases. Geochim Cosmochim Acta 44:933-941 doi: 10.1016/00167037(80)90283-5

O’Brien PJ, Zotov N, Law R, Khan MA, Jan MQ (2001) Coesite in Himalayan eclogite and implications for models of India-Asia collision. Geology 29:435-438 doi: $10.1130 / 0091-7613$

Parrish RR, Gough SJ, Searle MP, Waters DJ (2006) Plate velocity exhumation of ultrahigh-pressure eclogites in the Pakistan Himalaya. Geology 34:989-992 doi: 10.1130/G22796A.1

Pattison DRM (1992) Stability of andalusite and sillimanite and the $\mathrm{Al}_{2} \mathrm{SiO}_{5}$ triple point: constraints from the Ballachulish aureole, Scotland. J Geol 100:423-446 http://www.jstor.org/stable/30065741

Powell R, Holland TJB (1999) Relating formulations of the thermodynamics of mineral solid solutions; activity modeling of pyroxenes, amphiboles and micas. Amer Mineral 84:1-14 http://ammin.geoscienceworld.org/content/84/1-2/1.full.pdf 
Ravna EJK, Terry MP (2004) Geothermobarometry of UHP and HP eclogites and schists - an evaluation of equilibria among garnet-clinopyroxene-kyanite-phengitecoesite/quartz. J Metamorph Geol 22:579-592 doi: 10.1111/j.15251314.2004.00534.x

Sachan HK, Mukherjee BK, Ogaswara Y, Maruyama S, Ishida H, Muko A, Yoshika N (2004) Discovery of coesite from Indus Suture Zone (ISZ), Ladakh, India: evidence for deep subduction. Eur J Mineral 16:235-40 doi: 10.1127/0935-1221/2004/0016023

Štípská P, Powell R (2005) Constraining the P-T path of a MORB-type eclogite using pseudosections, garnet zoning and garnet-clinopyroxene thermometry: an example from the Bohemian Massif. J Metamorph Geol 23:725-743 doi: 10.1111/j.15251314.2005.00607.x

St-Onge MR, Rayner N, Palin RM, Searle MP, Waters DJ (2013) Integrated pressuretemperature-time constraints for the Tso Morari dome (Northwest India): implications for the burial and exhumation path of UHP units in the western Himalaya. J Metamorph Geol 31:469-504 doi:10.1111/jmg.12030

Syracuse EM, van Keken PE, Abers GA (2010) The global range of subduction zone thermal models. Phys Earth Planet Inter 183:73-90 doi:10.1016/j.pepi.2010.02.004

Thakur VC (1983) Deformation and metamorphism of the Tso Morari crystalline complex. In: Thakur VC, Sharma KK (eds) Geology of Indus Suture Zone of Ladakh, Wadia Institute of Himalayan Geology, Dehra Dun, India, pp 1-8 
Virdi NS, Thakur VC, Azmi RJ (1978) Discovery and significance of Permian microsfossils in the Tso Morari crystallines of Ladakh, India. Himalayan Geol 8:993-1000

Vogt K, Castro A, Gerya T (2013) Numerical modeling of geochemical variations caused by crustal relamination. Geochem Geophys Geosyst 14:470-487 doi:10.1002/ggge.20072

White RW, Powell R, Holland TJB (2001) Calculation of partial melting equilibria in the system $\mathrm{Na}_{2} \mathrm{O}-\mathrm{CaO}-\mathrm{K}_{2} \mathrm{O}-\mathrm{FeO}-\mathrm{MgO}-\mathrm{Al}_{2} \mathrm{O}_{3}-\mathrm{SiO}_{2}-\mathrm{H}_{2} \mathrm{O}$ (NCKFMASH). J Metamorph Geol 19:139-153 doi: 10.1046/j.0263-4929.2000.00303.x

White RW, Powell R, Holland TJB (2007) Progress relating to calculation of partial melting equilibria for metapelites. J Metamorph Geol 25:511-527 doi: 10.1111/j.1525-1314.2007.00711.x

Wilke FDH, O’Brien PJ, Gerdes A, Timmerman MJ, Sudo M, Khan MA (2010) The multistage exhumation history of the Kaghan Valley UHP series, NW Himalaya, Pakistan from U-Pb and ${ }^{40} \mathrm{Ar} /{ }^{39} \mathrm{Ar}$ ages. Eur J Mineral 22:703-719 doi: $10.1127 / 0935-1221 / 2010 / 0022-2051$

Zhu B, Kidd WSF, Rowley DB, Currie BS, Shafique N (2005) Age of initiation of the India-Asia collision in the eastern Himalaya. $\mathbf{J}$ Geol 113:265-286 doi: $10.1086 / 428805$

Figure captions: 
Fig 1 Simplified geological map of the Tso Morari area in northwestern Himalaya (after Epard and Steck 2008). The blue star represents sample location in this study and the small red stars represent known eclogite occurrences within the Tso Morari dome. The grey hexagons in the inset indicate the location of the Tso Morari and Kaghan eclogites in northwestern Himalayas.

Fig 2 A comparison of $P-T$ paths of metamorphism of the Tso Morari eclogite in previous studies (S97-de Sigoyer et al. 1997, G97-Guillot et al. 1997, M03Mukherjee et al. 2003, S13-St-Onge et al. 2013). The uncertainties are shown in blue (S97) and grey (S13) rectangles. The isopleths for phengite (Ph) and jadeite (Jd) from S97 and M03 are shown in blue and green respectively. Note that the positions of the $\mathrm{Si}$-in-phengite isopleths are based on assemblages containing $\mathrm{K}$ feldspar-phlogopite-quartz in S97, and talc-kyanite-coesite in M03. G97 and the $<2 \mathrm{GPa}$ stages of S13 were determined in the metapelites associated with the eclogites. The $P-T$ path for the Kaghan eclogite (K03-Kaneko et al. 2003), the kyanite (Ky)-sillimanite (Sil)-andalusite (And) stability limits (Pattison 1992), the quartz-coesite transition (Bohlen and Boettcher 1992) and the graphite-diamond transition (Bundy 1980) are shown for reference.

Fig 3 Compositions of minerals in the Tso Morari eclogites. (a-b) Clinopyroxene plotted according to Morimoto et al. (1988); Quad-quadrilateral pyroxene components. (c-d) Amphibole plotted according to Leake et al. (1997). (e-f) Epidoteclinozoisite, $\mathrm{Fe}^{3+}$ calculated according to Armbruster et al. (2006). (g-h) Mica. 
Fig 4 Eclogite textures. (a) Large area BSE image showing the distribution of garnet porphyroblasts (light) in a coarse-grained matrix (dark). (b) Large area Fe X-ray map showing the relative abundance of phases. (c) Carbon X-ray map of the area in (c) showing the relative abundance of carbonates (green) in the matrix. (d) Polymineralic inclusion in garnet. (e) Silica with possible relict coesite inclusion showing radial fractures emanating into the host garnet. (f) Coarse-grained matrix. (g) Fine-grained intergrowth around porphyroblasts. Ab-albite; Act-actinolite; Ap-apatite; Aug-augite; Brs-barroisite; Cal-calcite; Coe-coesite; Dol-dolomite; Ep-epidote; Grt-garnet; Ilm-ilmenite; Omp-omphacite; Ph-phengite; Qz-quartz; Rt-rutile; Zrn-zircon.

Fig 5 X-ray maps and rim-to-rim compositional variations in garnet porphyroblasts in sample LB09-8.1. (a) Mg X-ray map. (b) Ca X-ray map showing inclusion-rich core. The abbreviations are as in Fig. 4, and Alm-almandine; Grs-grossular; Prppyrope; Sps-spessartine; Trm-taramite. The red lines in the grossular concentration profiles depict the results of Ca-diffusion modeling. Note that the images are cropped to show only a thin region (red or blue) of the matrix surrounding garnet.

Fig 6 BSE image and rim-to-rim compositional variations in garnet porphyroblasts in LB09-9.3. The abbreviations are as in Figs. 4 and 5, and Adr-andradite; Fprgferropargasite; Mtm-magnesiotaramite; Pg-paragonite; and Zo-zoisite. The red lines in the grossular concentration profiles are the results of Ca-diffusion modeling. 
Fig 7 Equilibrium $P$ - $T$ estimates using the mineral compositions in Table 2 and the thermobarometric formulations of Ravna and Terry (2004). The sample names LB09-8.1 and LB09-9.3 are shortened as 8.1 and 9.3. The abbreviations for mineral domains are: c-core, oc-outer core, ir-inner rim, and r-rim. The rectangles depict the uncertainties in $P( \pm 0.32 \mathrm{GPa})$ and $T\left( \pm 82{ }^{\circ} \mathrm{C}\right)$ recommended in the above study. The arrows indicate core-to-rim heating trajectories (see text).

Fig $8 P$-T pseudosection for the bulk composition of 8.1A. (a) Phase stability limits. (b-d) Mineral composition isopleths. (d) Garnet volume percent contours. The analyzed compositions of omphacite and garnet cores plot in the red and purple shaded regions respectively. The arrow indicates the $P-T$ path. The $P-T$ 's of cores obtained from thermobarometry are shown by stars (see Fig. 7). The quartzcoesite transition (Bohlen and Boettcher 1992) is shown in (a). (Amp-amphibole; Mica-phengitic mica; lws-lawsonite, arg-aragonite; the abbreviations for the solid solutions start with a capital letter).

Fig $9 P-T$ pseudosection for the bulk composition of 9.3A. (a) Phase stability limits. (b) Garnet composition isopleths, the inferred $P-T$ path (bold dashed line) and two hypothetical $P-T$ paths for the garnet core. The analyzed average composition of the central part of the garnet cores approximately plots in the purple shaded region and the compositional variation along the $P-T$ path is consistent with the compositional trend analyzed in the garnet core. The $P-T$ 's of cores and rims obtained from thermobarometry are shown by stars (see Fig. 7). The calculated 
garnet composition in the large red shaded region approaches the analyzed composition of the garnet rim which is better modeled in Fig. 12 using the bulk composition of 9.3B. (c) Comparison of analyzed (thick, grey dashed line) and calculated garnet compositions along the modeled (thick, black dashed line) and two hypothetical $P-T$ paths (thin, black dashed lines) from the center to the outer part of the garnet core. Of the three $P-T$ paths shown in (b), the modeled path provides the closest fit, whereas both Paths I (for Grs and Prp) and II (for Grs) fail to reproduce the garnet core compositions. (Chl-chlorite; mag-magnetite).

Fig $10 P-T$ pseudosection for the bulk compositions of 8.1B. (a) Phase stability limits. Plagioclase is stable only at pressures below the bold dashed line ( 1.6-1.7 GPa), and melt is present between the two thin dashed lines in the middle part of the diagram. (b) Garnet composition isopleths. The analyzed garnet outer rim composition does not plot in this diagram. However, the isopleths closely approach the analyzed composition in the barred oval area. (Cpx-clinopyroxene; Ph-mica; Pl-plagioclase).

Fig $11 T-\mathrm{M}_{\mathrm{CO} 2}$ pseudosection at $1.8 \mathrm{GPa}$ for the bulk composition of $8.1 \mathrm{~B}$ showing garnet composition isopleths. The analyzed compositions of the garnet outer rims plot in the green shaded region.

Fig $12 P-T$ pseudosection for the bulk compositions of 9.3B. (a) Phase stability limits. Plagioclase is stable only at pressures below the bold dashed line ( 1.4-1.7 GPa), and melt is present on the higher- $T$ side of the thin dashed line. (b) Garnet composition isopleths. The analyzed compositions of garnet outer rims plot in the 
green shaded region. The region for the garnet rims from Fig. 9 is also shown for comparison.

Fig $13 P$ - $T$ pseudosections constructed using the bulk compositions of (a) $8.1 \mathrm{C}$ and (b) 9.3C. The analyzed compositions of augite and actinolite plot in the blue shaded circular region in (a), and the analyzed compositions of plagioclase and biotite plot in the blue shaded circular region in (b). The diameter of the shaded circles represents the uncertainties in pressure and temperature.

Fig 14 (a) $P-T$ path of exhumation of the Tso Morari eclogite in this study (thick red and blue dashed line) compared with the thermal conditions of slab surfaces in active subduction zones (Syracuse et al. 2010). Segments of the $P-T$ path in this study: open red boxes: $P-T$ of garnet core (stage A), solid red boxes: $P-T$ of garnet rim (stage B), blue boxes: $P-T$ of plagioclase-actinolite-biotite (stage C). Red rectangles: $P-T$ estimates from pseudosections (dashed borders represent minimum uncertainties). Bold arrows depict heating trajectories from core to rim of minerals from thermobarometry (Fig. 7). Also shown for comparison are the range of numerically simulated $P-T$ paths of slab crust exhumed as part of a collisional orogen (purple shaded region, Faccenda et al. 2008) and as partially molten translithospheric diapirs through the mantle wedge (light red shaded region, Vogt et al. 2013), $P-T$ paths from earlier studies (see Fig. 2), and $P-T$ conditions of garnet in this study (solid diamond: core, open diamond: outer rim; note dual solution for the rim) using the isopleths of St-Onge et al. (2013). (b) Cartoon showing Indian crust subducting under the Kohistan-Ladakh arc, and the 
exhumation of Tso Morari eclogite by diapiric ascent through the mantle wedge

(Path I) compared with exhumation through a subduction channel (Path II).

Tables:

Table 1 Compositions of garnet and clinopyroxene in Tso Morari eclogite

Table 2 Mineral compositions used in and $P-T$ results of thermobarometry

Table 3 Mineral abundances and bulk composition of assemblages

Table 1 Compositions of garnet and clinopyroxene in Tso Morari eclogite

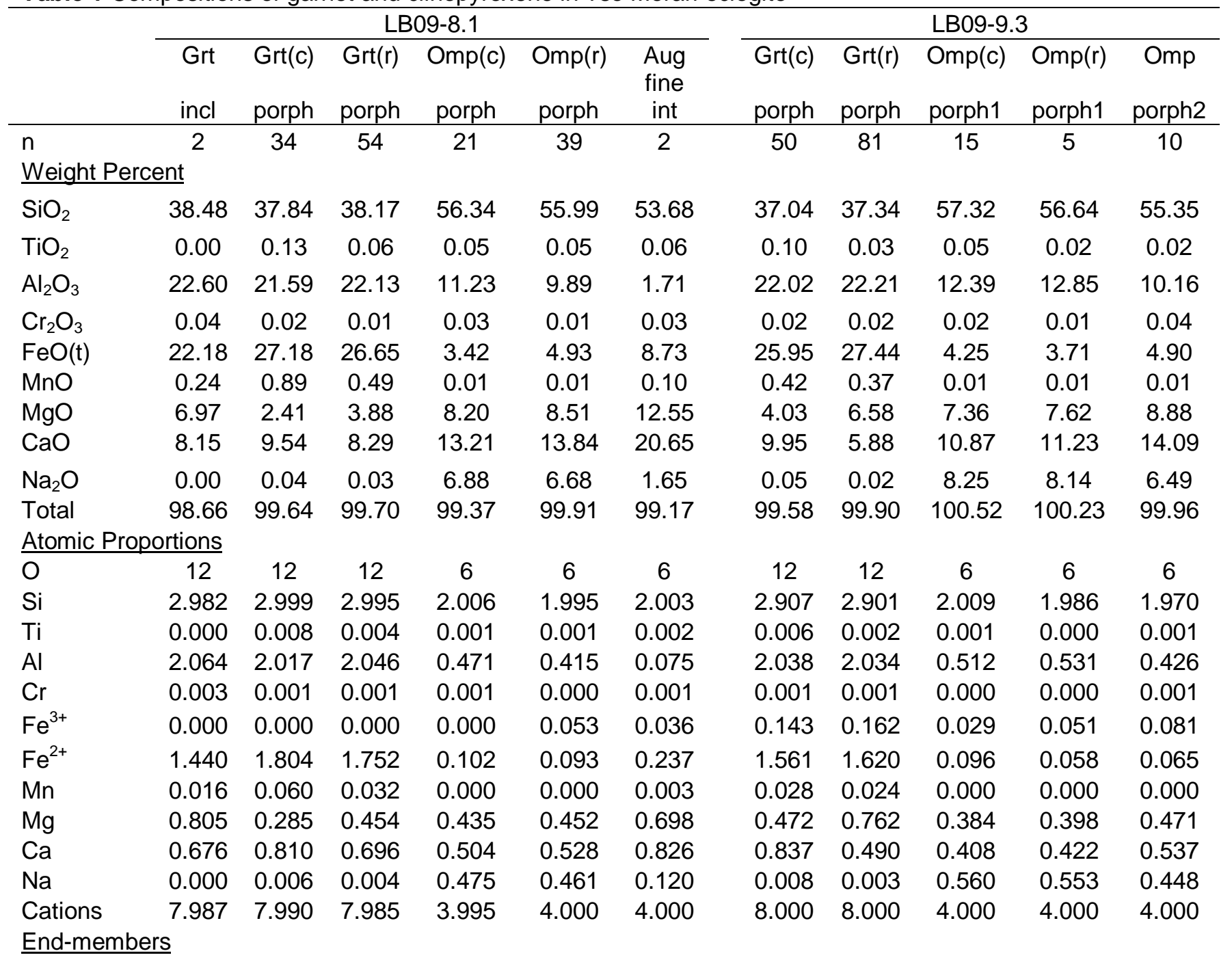


Page 40 of 56

\begin{tabular}{lccccccccccc} 
Adr or Aug & 0.0 & 0.0 & 0.0 & 52.3 & 53.8 & 88.0 & 1.9 & 1.2 & 44.4 & 43.9 & 53.7 \\
Alm or Jd & 49.0 & 61.0 & 59.7 & 47.7 & 40.9 & 8.0 & 53.9 & 55.9 & 52.8 & 54.4 & 43.3 \\
Sps or Aeg & 0.5 & 2.0 & 1.1 & 0.0 & 5.3 & 4.7 & 1.0 & 0.8 & 5.0 & 2.3 & 2.2 \\
Prp & 27.4 & 9.6 & 15.5 & - & - & - & 16.3 & 26.3 & - & - & - \\
Grs & 23.0 & 27.3 & 23.7 & - & - & - & 26.9 & 15.6 & - & - & - \\
\hline
\end{tabular}

n-number of analyses; t-total Fe as FeO; c-core; r-rim; incl-inclusion; porph-porphyroblast.

$\mathrm{Fe}^{3+}$ and $\mathrm{Fe}^{2+}$ calculated through charge balancing.

Omp end-members are according to Morimoto et al. (1988). 
Table 2 Mineral compositions used in and $P-T$ results of thermobarometry

\begin{tabular}{|c|c|c|c|c|c|c|c|c|c|}
\hline \multirow[b]{2}{*}{$\begin{array}{l}\text { Mineral } \\
\text { Textural } \\
\text { setting }\end{array}$} & \multicolumn{9}{|c|}{ LB09-8.1 } \\
\hline & $\begin{array}{c}\text { Grt } \\
\text { porphyro- } \\
\text { blast }\end{array}$ & $\begin{array}{c}\text { Omp } \\
\text { porphyro- } \\
\text { blast }\end{array}$ & $\begin{array}{l}\mathrm{Ph} \\
\text { large } \\
\text { matrix } \\
\text { grain }\end{array}$ & $\begin{array}{c}\text { Grt } \\
\text { porphyro- } \\
\text { blast }\end{array}$ & $\begin{array}{c}\text { Omp } \\
\text { incl. at } \\
\text { Grt core- } \\
\text { rim } \\
\text { contact }\end{array}$ & $\begin{array}{c}\mathrm{Ph} \\
\text { large } \\
\text { matrix } \\
\text { grain }\end{array}$ & $\begin{array}{c}\text { Grt } \\
\text { porphyro- } \\
\text { blast }\end{array}$ & $\begin{array}{c}\text { Omp } \\
\text { incl. at } \\
\text { Grt core- } \\
\text { rim } \\
\text { contact }\end{array}$ & $\begin{array}{c}\mathrm{Ph} \\
\text { large } \\
\text { matrix } \\
\text { grain }\end{array}$ \\
\hline $\begin{array}{l}\text { Point } \\
\text { location }\end{array}$ & $\begin{array}{l}\text { core } \\
\text { avg. }\end{array}$ & $\begin{array}{l}\text { core } \\
\text { avg. }\end{array}$ & $\begin{array}{l}\text { core } \\
\text { avg. }\end{array}$ & $\begin{array}{l}\text { outer } \\
\text { core }\end{array}$ & core & $\begin{array}{l}\text { outer } \\
\text { core }\end{array}$ & inner rim & core & rim \\
\hline \multicolumn{10}{|c|}{ Weight Percent } \\
\hline $\mathrm{SiO}_{2}$ & 37.84 & 56.34 & 52.90 & 38.08 & 56.27 & 52.70 & 38.49 & 56.27 & 51.07 \\
\hline $\mathrm{TiO}_{2}$ & 0.13 & 0.05 & 0.21 & 0.10 & 0.04 & 0.24 & 0.07 & 0.04 & 0.21 \\
\hline $\mathrm{Al}_{2} \mathrm{O}_{3}$ & 21.59 & 11.23 & 24.86 & 22.08 & 10.80 & 25.19 & 22.50 & 10.80 & 28.04 \\
\hline $\mathrm{Cr}_{2} \mathrm{O}_{3}$ & 0.02 & 0.03 & 0.00 & 0.03 & 0.00 & 0.00 & 0.00 & 0.00 & 0.00 \\
\hline $\mathrm{FeO}$ & 27.18 & 3.42 & 1.50 & 28.45 & 6.54 & 1.63 & 27.26 & 6.54 & 1.32 \\
\hline $\mathrm{MnO}$ & 0.89 & 0.01 & 0.01 & 0.62 & 0.01 & 0.02 & 0.51 & 0.01 & 0.02 \\
\hline $\mathrm{MgO}$ & 2.41 & 8.20 & 4.56 & 1.85 & 6.98 & 4.28 & 4.34 & 6.98 & 3.67 \\
\hline $\mathrm{CaO}$ & 9.54 & 13.21 & 0.01 & 9.85 & 12.49 & 0.00 & 7.48 & 12.49 & 0.04 \\
\hline $\mathrm{Na}_{2} \mathrm{O}$ & & 6.88 & 0.40 & & 7.35 & 0.37 & & 7.35 & 0.92 \\
\hline $\mathrm{K}_{2} \mathrm{O}$ & & & 9.80 & & & 9.67 & & & 9.22 \\
\hline \multirow[t]{2}{*}{$\mathrm{P} / \mathrm{T}$} & \multicolumn{3}{|c|}{ core: $2.46 \mathrm{GPa} / 458{ }^{\circ} \mathrm{C}$} & \multicolumn{3}{|c|}{ outer core: $2.41 \mathrm{GPa} / 484{ }^{\circ} \mathrm{C}$} & \multicolumn{3}{|c|}{ inner rim: $2.31 \mathrm{GPa} / 627^{\circ} \mathrm{C}$} \\
\hline & \multicolumn{3}{|c|}{ LB09-8.1 } & \multicolumn{6}{|c|}{ LB09-9.3 } \\
\hline $\begin{array}{l}\text { Mineral } \\
\text { Textural } \\
\text { setting }\end{array}$ & $\begin{array}{c}\text { Grt } \\
\text { porphyro- } \\
\text { blast }\end{array}$ & $\begin{array}{c}\text { Omp } \\
\text { porphyro- } \\
\text { blast }\end{array}$ & $\begin{array}{c}\mathrm{Ph} \\
\text { large } \\
\text { matrix } \\
\text { grain }\end{array}$ & $\begin{array}{c}\text { Grt } \\
\text { porphyro- } \\
\text { blast }\end{array}$ & $\begin{array}{c}\text { Omp } \\
\text { porphyro- } \\
\text { blast }\end{array}$ & $\begin{array}{c}\mathrm{Ph} \\
\text { incl. in } \\
\text { Grt } \\
\text { core }\end{array}$ & $\begin{array}{c}\text { Grt } \\
\text { porphyro- } \\
\text { blast }\end{array}$ & $\begin{array}{c}\text { Omp } \\
\text { porphyro- } \\
\text { blast }\end{array}$ & $\begin{array}{c}\mathrm{Ph} \\
\text { large } \\
\text { matrix } \\
\text { grain }\end{array}$ \\
\hline $\begin{array}{l}\text { Point } \\
\text { location }\end{array}$ & rim & rim & rim & $\begin{array}{l}\text { core } \\
\text { avg. }\end{array}$ & core & - & rim & rim & rim \\
\hline \multicolumn{10}{|c|}{ Weight Percent } \\
\hline $\mathrm{SiO}_{2}$ & 38.65 & 56.10 & 51.07 & 37.04 & 57.01 & 50.97 & 37.31 & 56.67 & 50.05 \\
\hline $\mathrm{TiO}_{2}$ & 0.15 & 0.13 & 0.21 & 0.10 & 0.05 & 0.23 & 0.02 & 0.02 & 0.27 \\
\hline $\mathrm{Al}_{2} \mathrm{O}_{3}$ & 21.97 & 11.22 & 28.04 & 22.02 & 11.54 & 27.38 & 22.02 & 12.10 & 28.45 \\
\hline $\mathrm{Cr}_{2} \mathrm{O}_{3}$ & 0.00 & 0.00 & 0.00 & 0.02 & 0.01 & 0.00 & 0.01 & 0.00 & 0.06 \\
\hline $\mathrm{FeO}$ & 23.25 & 3.51 & 1.32 & 25.95 & 4.78 & 3.12 & 25.28 & 3.90 & 2.27 \\
\hline $\mathrm{MnO}$ & 0.24 & 0.01 & 0.02 & 0.42 & 0.00 & 0.02 & 0.36 & 0.00 & 0.00 \\
\hline $\mathrm{MgO}$ & 6.13 & 7.57 & 3.67 & 4.03 & 7.92 & 3.10 & 9.25 & 7.97 & 3.42 \\
\hline $\mathrm{CaO}$ & 8.87 & 13.12 & 0.04 & 9.95 & 11.63 & 0.06 & 4.90 & 11.72 & 0.01 \\
\hline $\mathrm{Na}_{2} \mathrm{O}$ & & 6.94 & 0.92 & & 7.95 & 1.03 & & 7.71 & 0.36 \\
\hline $\mathrm{K}_{2} \mathrm{O}$ & & & 9.22 & & & 8.53 & & & 9.81 \\
\hline $\mathrm{P} / \mathrm{T}$ & \multicolumn{3}{|c|}{ rim: $2.68 \mathrm{GPa} / 690{ }^{\circ} \mathrm{C}$} & \multicolumn{3}{|c|}{ core: $2.24 \mathrm{GPa} / 480{ }^{\circ} \mathrm{C}$} & \multicolumn{3}{|c|}{ rim: $2.05 \mathrm{GPa} / 547^{\circ} \mathrm{C}$} \\
\hline $\begin{array}{l}\text { Except } \\
\text { barome } \\
\text { formula }\end{array}$ & $\begin{array}{l}\text { LB09-9.3 } \\
\text { The excep } \\
\text { s are from }\end{array}$ & $\begin{array}{l}\text { im, all calcu } \\
\text { ption is base } \\
\text { Ravna and }\end{array}$ & $\begin{array}{l}\text { ations a } \\
\text { d on the } \\
\text { Terry (2 }\end{array}$ & $\begin{array}{l}\text { ased on the } \\
\text { Cpx-Ky-Qz }\end{array}$ & $\begin{array}{l}\text { Grt-Cpx Fe } \\
\text { thermomet }\end{array}$ & $\begin{array}{l}\text { Ig ther } \\
\text { and th }\end{array}$ & $\begin{array}{l}\text { ter and the } \\
\text { Cpx-Phe ba }\end{array}$ & $\begin{array}{l}\text { Grt-Cpx-P } \\
\text { arometer. T }\end{array}$ & \\
\hline
\end{tabular}


Page 42 of 56

Table 3 Mineral abundances and bulk composition of assemblages

\begin{tabular}{|c|c|c|c|c|c|c|}
\hline & \multicolumn{3}{|c|}{ LB08-8.1 } & \multicolumn{3}{|c|}{ LB08-9.3 } \\
\hline & $8.1 \mathrm{~A}$ & $8.1 \mathrm{~B}$ & $8.1 \mathrm{C}$ & $9.3 \mathrm{~A}$ & $9.3 \mathrm{~B}$ & $9.3 \mathrm{C}$ \\
\hline \multicolumn{7}{|l|}{ Volume \% } \\
\hline Grt & 3.9 & 10.3 & - & - & 31.1 & - \\
\hline Cpx & - & 40.7 & 5.0 & - & 35.3 & - \\
\hline $\mathrm{Brs}$ & 30.3 & 8.2 & - & 42.6 & 11.6 & - \\
\hline Trm & - & - & - & 30.0 & - & 22.5 \\
\hline Prg & - & - & - & 14.5 & - & 9.1 \\
\hline Act & - & - & 47.5 & - & - & - \\
\hline Ep/Zo & 14.5 & 8.9 & - & - & 3.5 & - \\
\hline $\mathrm{Pg}$ & 6.6 & 8.7 & - & 2.0 & 6.4 & - \\
\hline $\mathrm{Ph}$ & 6.6 & - & - & 2.0 & 4.3 & 35.9 \\
\hline $\mathrm{Bt}$ & - & - & - & - & - & 2.1 \\
\hline $\mathrm{Pl}$ & - & - & 47.5 & - & - & 30.4 \\
\hline Ky & - & - & - & - & 0.2 & - \\
\hline Qz & 19.7 & 7.4 & - & 2.9 & 0.9 & - \\
\hline Rt & 3.9 & 4.2 & - & 3.7 & 1.5 & - \\
\hline IIm & - & - & - & 1.4 & 0.3 & - \\
\hline Dol & 3.3 & 11.7 & - & 1.0 & 3.4 & - \\
\hline Cal & 11.2 & - & - & - & 1.5 & - \\
\hline Mgs & - & - & - & - & 0.1 & - \\
\hline \multicolumn{7}{|l|}{ Bulk Wt\% } \\
\hline $\mathrm{SiO}_{2}$ & 47.9 & 45.4 & 60.4 & 44.8 & 45.3 & 52.5 \\
\hline $\mathrm{TiO}_{2}$ & 4.1 & 4.3 & n.d. & 4.6 & 1.7 & 0.1 \\
\hline $\mathrm{Al}_{2} \mathrm{O}_{3}$ & 12.9 & 13.4 & 12.0 & 15.5 & 17.4 & 21.8 \\
\hline $\mathrm{Fe}_{2} \mathrm{O}_{3}$ & 1.3 & 1.5 & 0.3 & 2.2 & 1.9 & 1.6 \\
\hline $\mathrm{FeO}$ & 5.7 & 5.8 & 4.6 & 9.3 & 9.5 & 5.0 \\
\hline $\mathrm{MgO}$ & 4.4 & 6.8 & 8.4 & 10.1 & 7.4 & 4.7 \\
\hline $\mathrm{CaO}$ & 13.3 & 12.9 & 6.9 & 8.1 & 9.3 & 3.5 \\
\hline $\mathrm{Na}_{2} \mathrm{O}$ & 1.8 & 3.7 & 6.3 & 3.5 & 3.8 & 4.5 \\
\hline $\mathrm{K}_{2} \mathrm{O}$ & 0.7 & 0.02 & n.d. & 0.4 & 0.5 & 3.8 \\
\hline $\mathrm{H}_{2} \mathrm{O}$ & 1.3 & 0.6 & 0.9 & 1.0 & 0.8 & 2.4 \\
\hline $\begin{array}{l}\mathrm{CO}_{2} \\
\text { Bulk Mole\% }\end{array}$ & 6.5 & 5.4 & n.d. & 0.5 & 2.3 & n.d. \\
\hline $\mathrm{SiO}_{2}$ & 47.9 & 45.8 & 60.0 & 46.0 & 47.1 & 54.8 \\
\hline $\mathrm{TiO}_{2}$ & 3.1 & 3.3 & n.d. & 3.5 & 1.4 & 0.1 \\
\hline $\mathrm{Al}_{2} \mathrm{O}_{3}$ & 7.6 & 8.0 & 7.0 & 9.4 & 10.6 & 13.4 \\
\hline $\mathrm{Fe}_{2} \mathrm{O}_{3}$ & 0.5 & 0.6 & 0.1 & 0.9 & 0.7 & 0.6 \\
\hline $\mathrm{FeO}$ & 4.7 & 4.9 & 3.9 & 8.0 & 8.3 & 4.3 \\
\hline $\mathrm{MgO}$ & 6.5 & 10.3 & 12.4 & 15.4 & 11.5 & 7.4 \\
\hline $\mathrm{CaO}$ & 14.3 & 14.0 & 7.3 & 8.9 & 10.3 & 3.9 \\
\hline $\mathrm{Na}_{2} \mathrm{O}$ & 1.7 & 3.6 & 6.1 & 3.4 & 3.8 & 4.6 \\
\hline $\mathrm{K}_{2} \mathrm{O}$ & 0.5 & 0.0 & n.d. & 0.3 & 0.3 & 2.5 \\
\hline $\mathrm{H}_{2} \mathrm{O}$ & 4.3 & 2.2 & 3.1 & 3.6 & 2.6 & 8.3 \\
\hline
\end{tabular}


n.d.

0.6

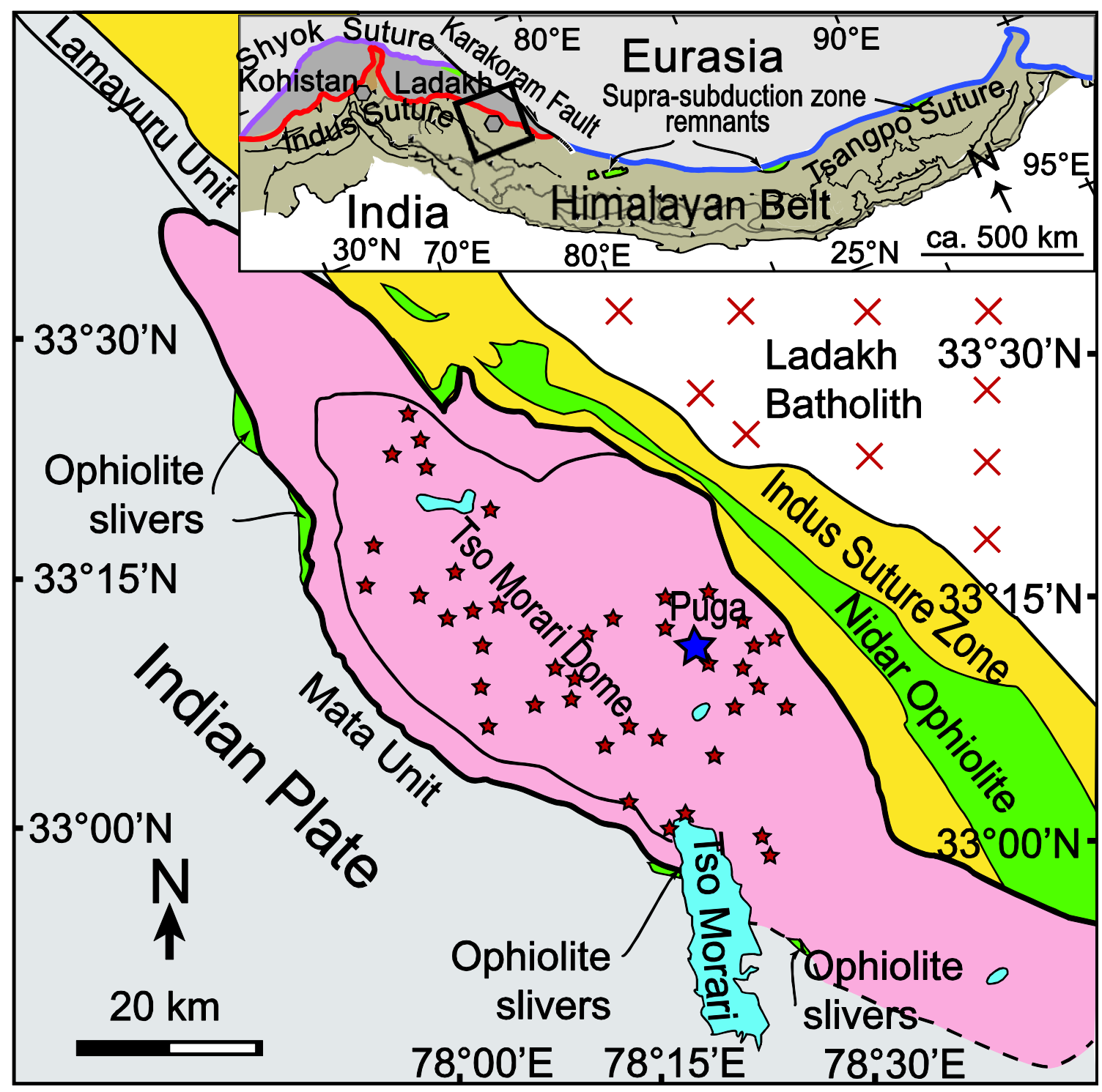


Page 44 of 56

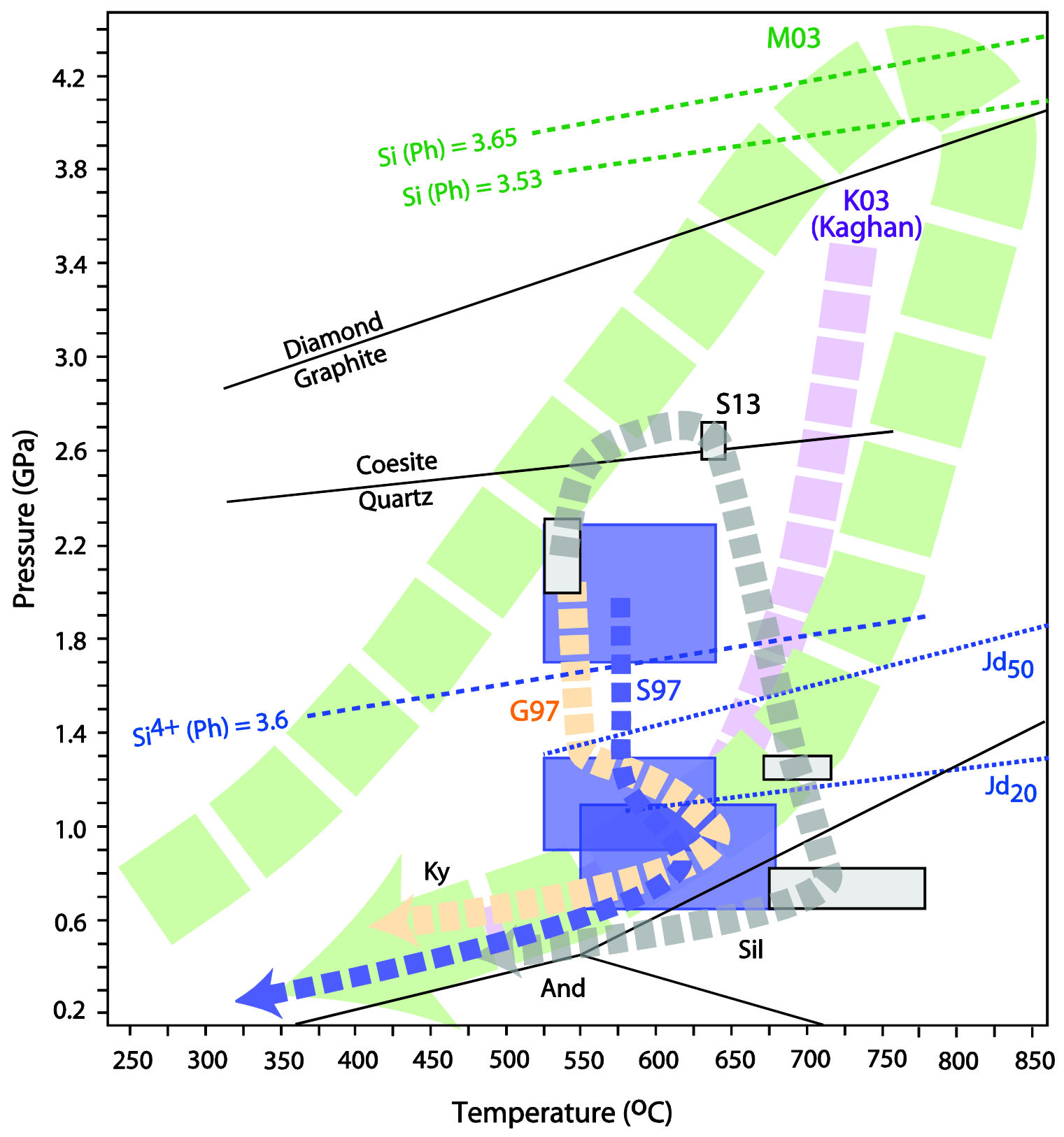



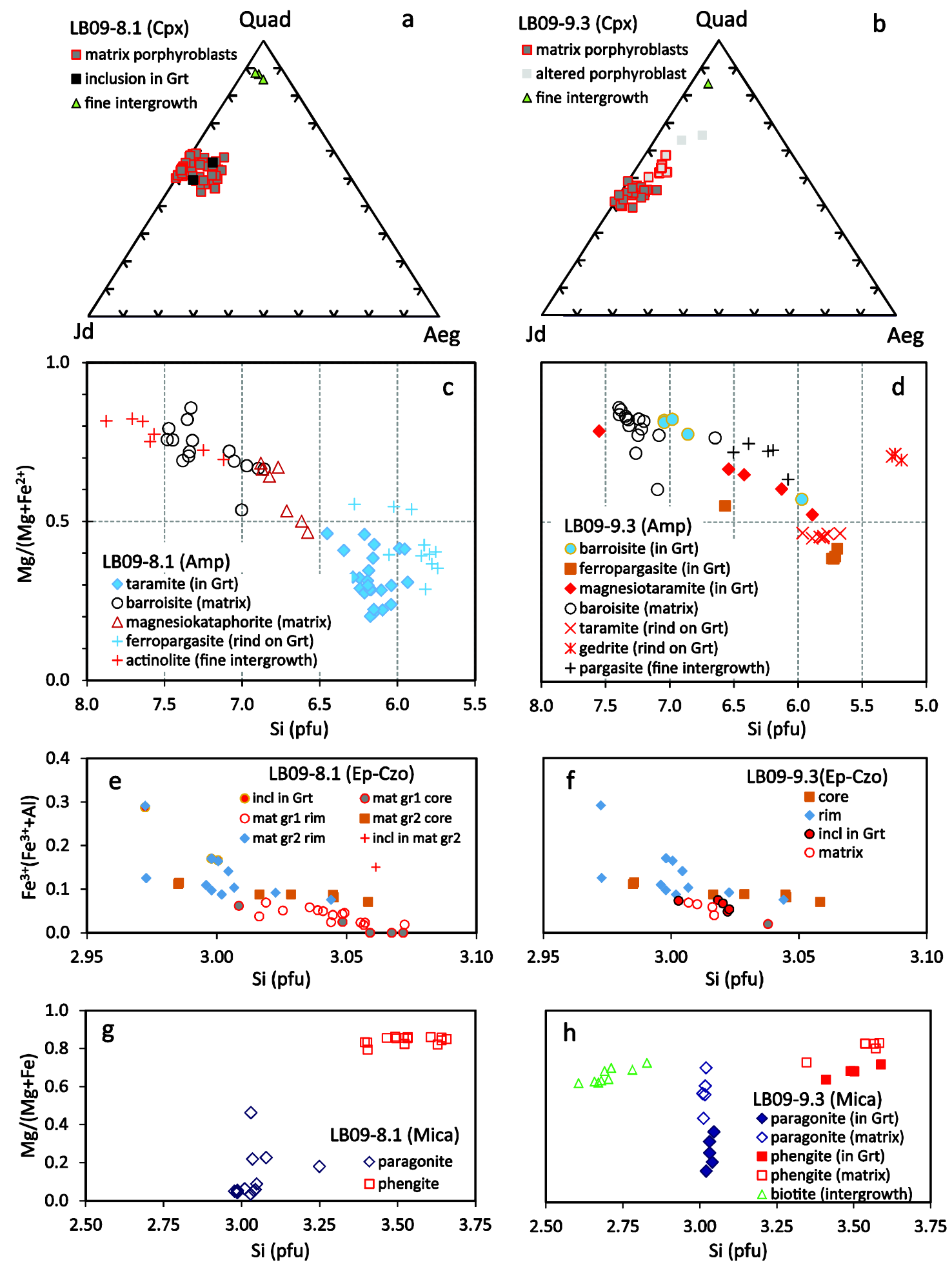


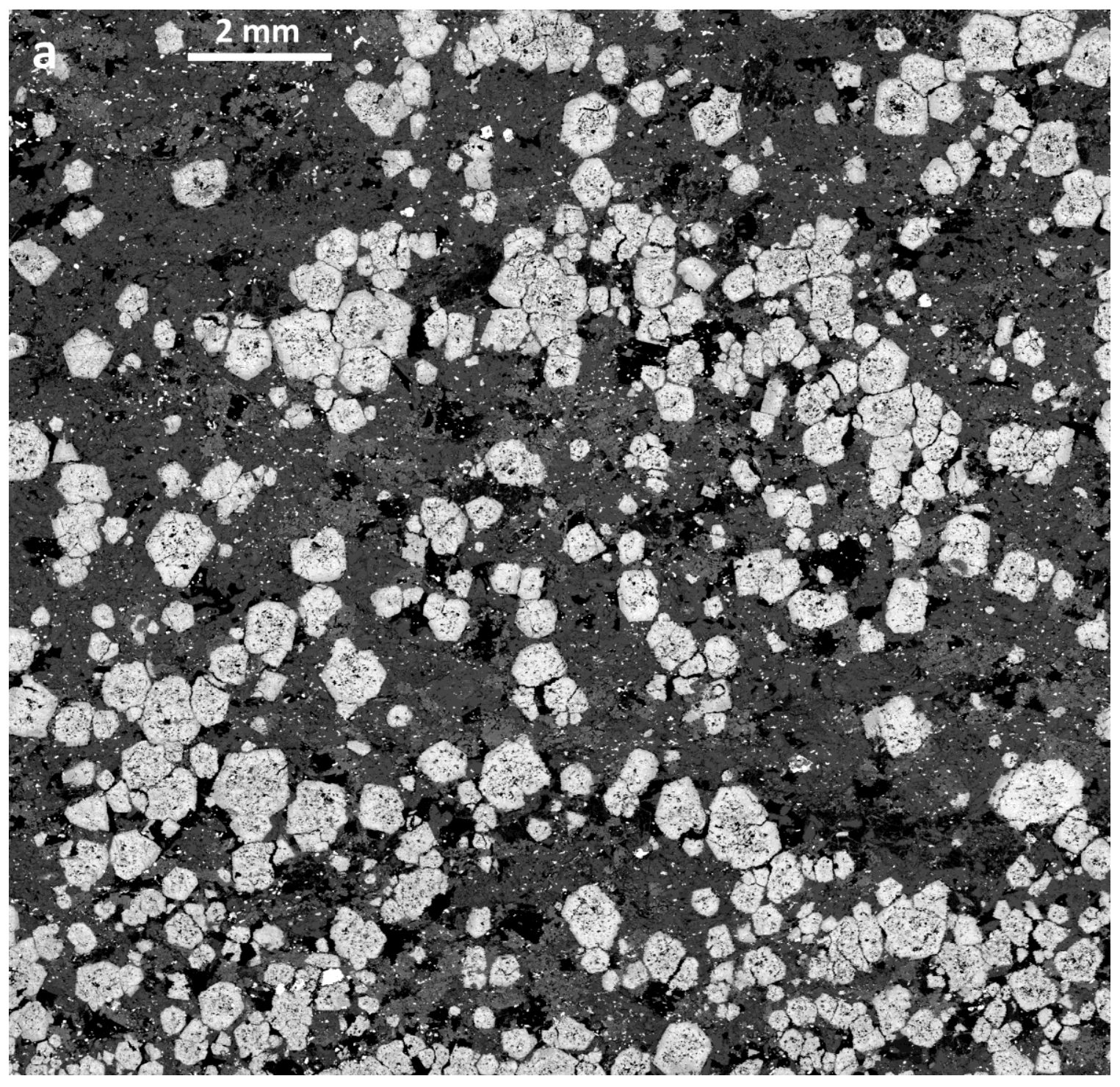




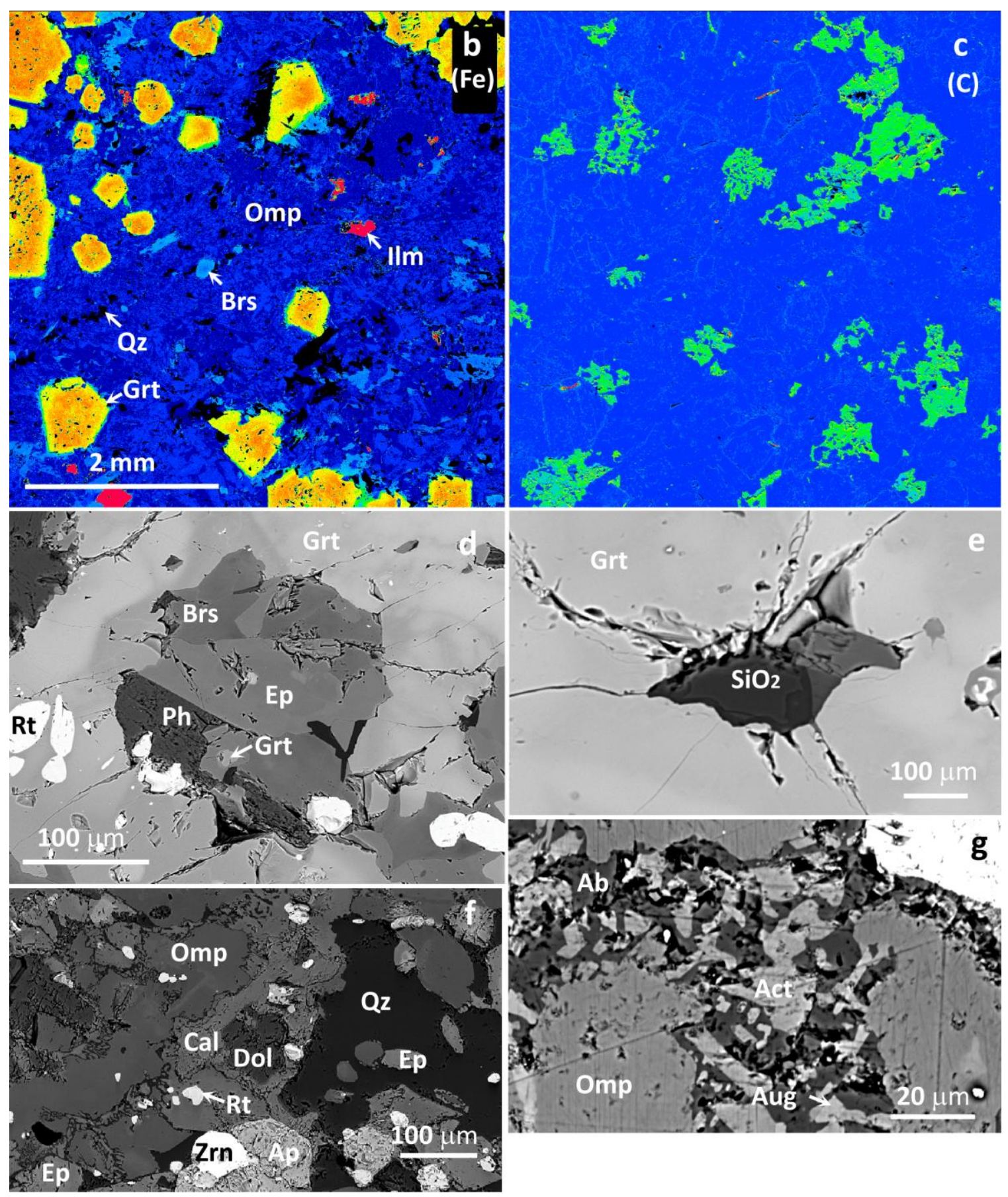




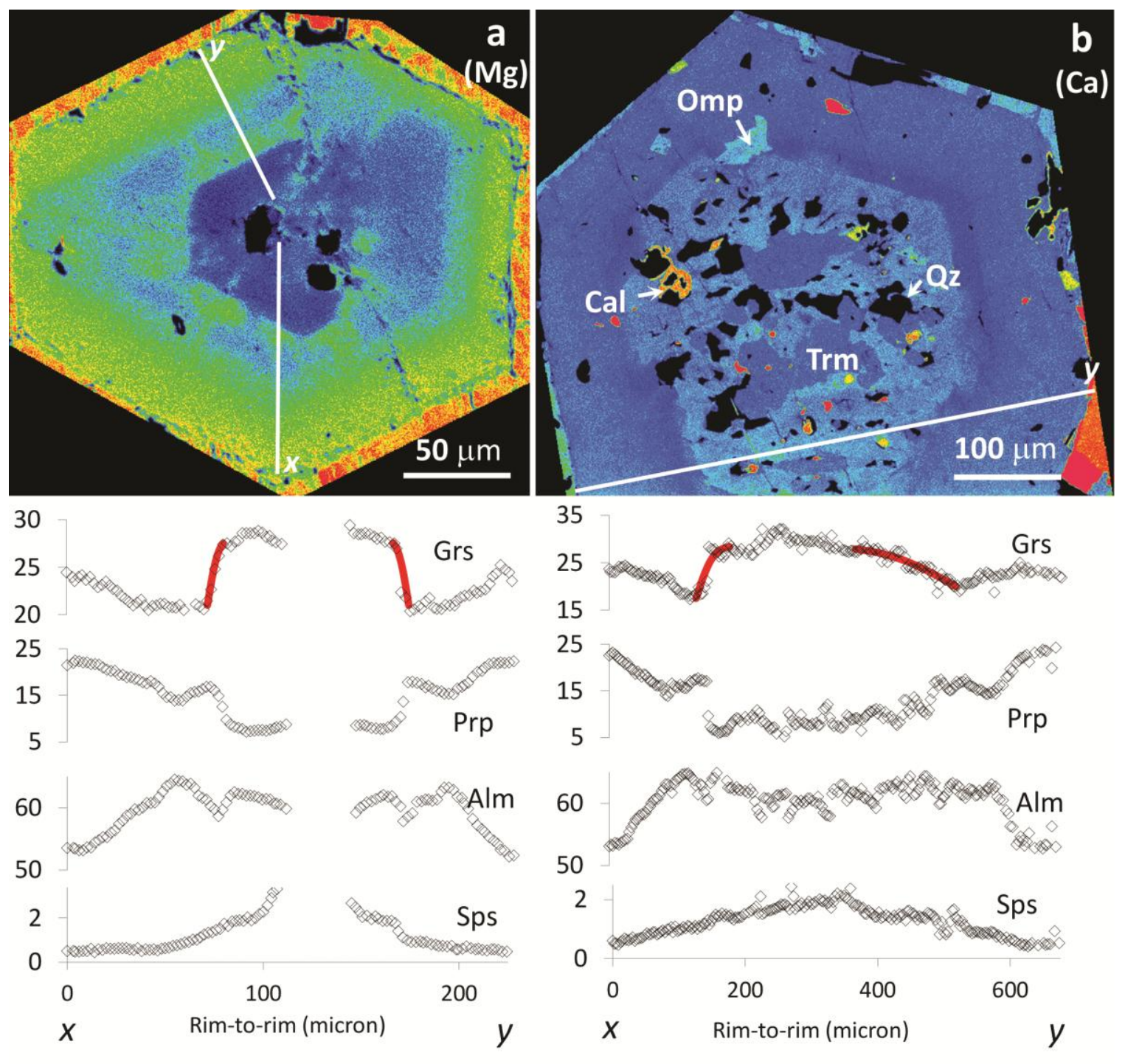



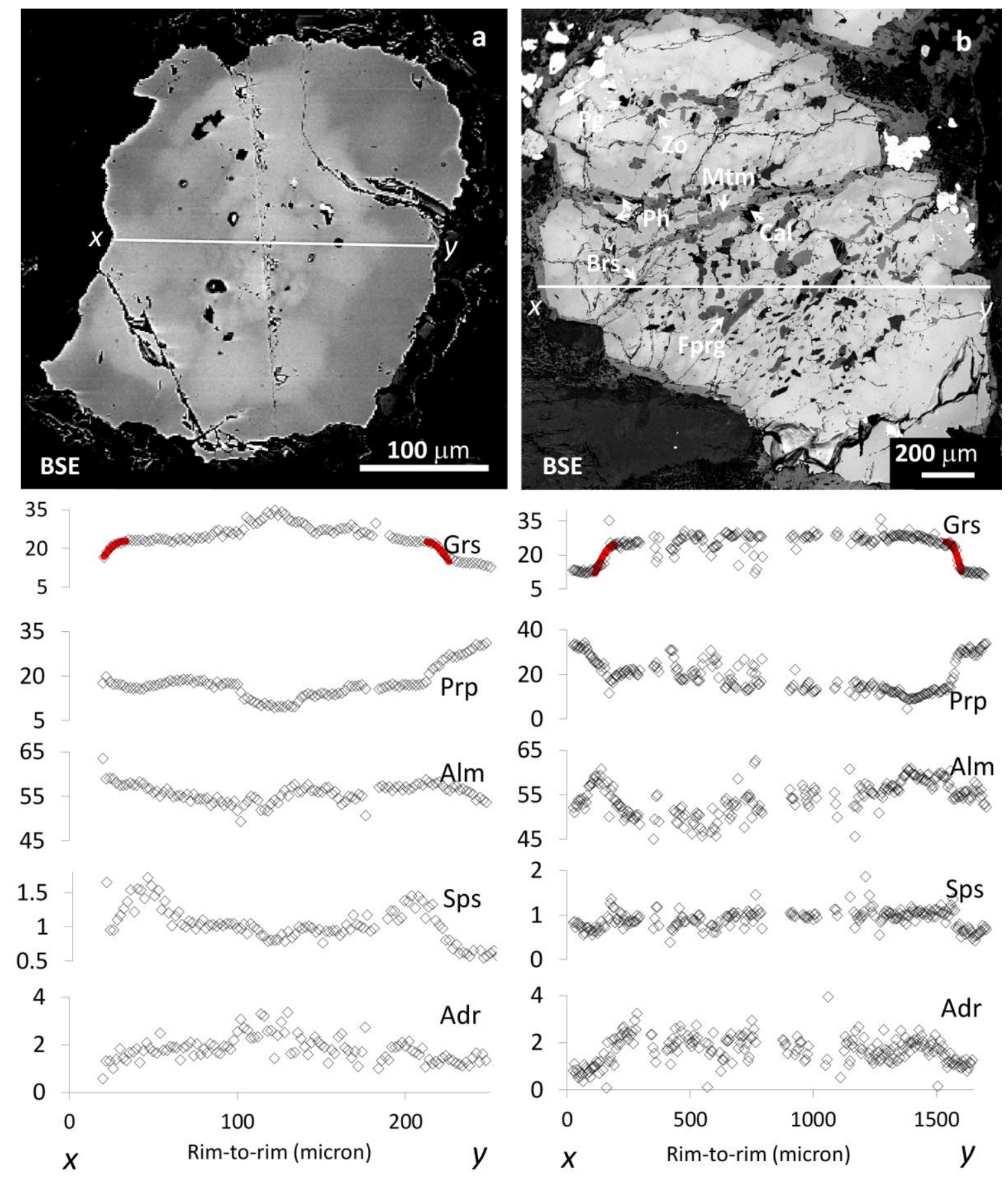
Page $\mathbf{5 0}$ of $\mathbf{5 6}$

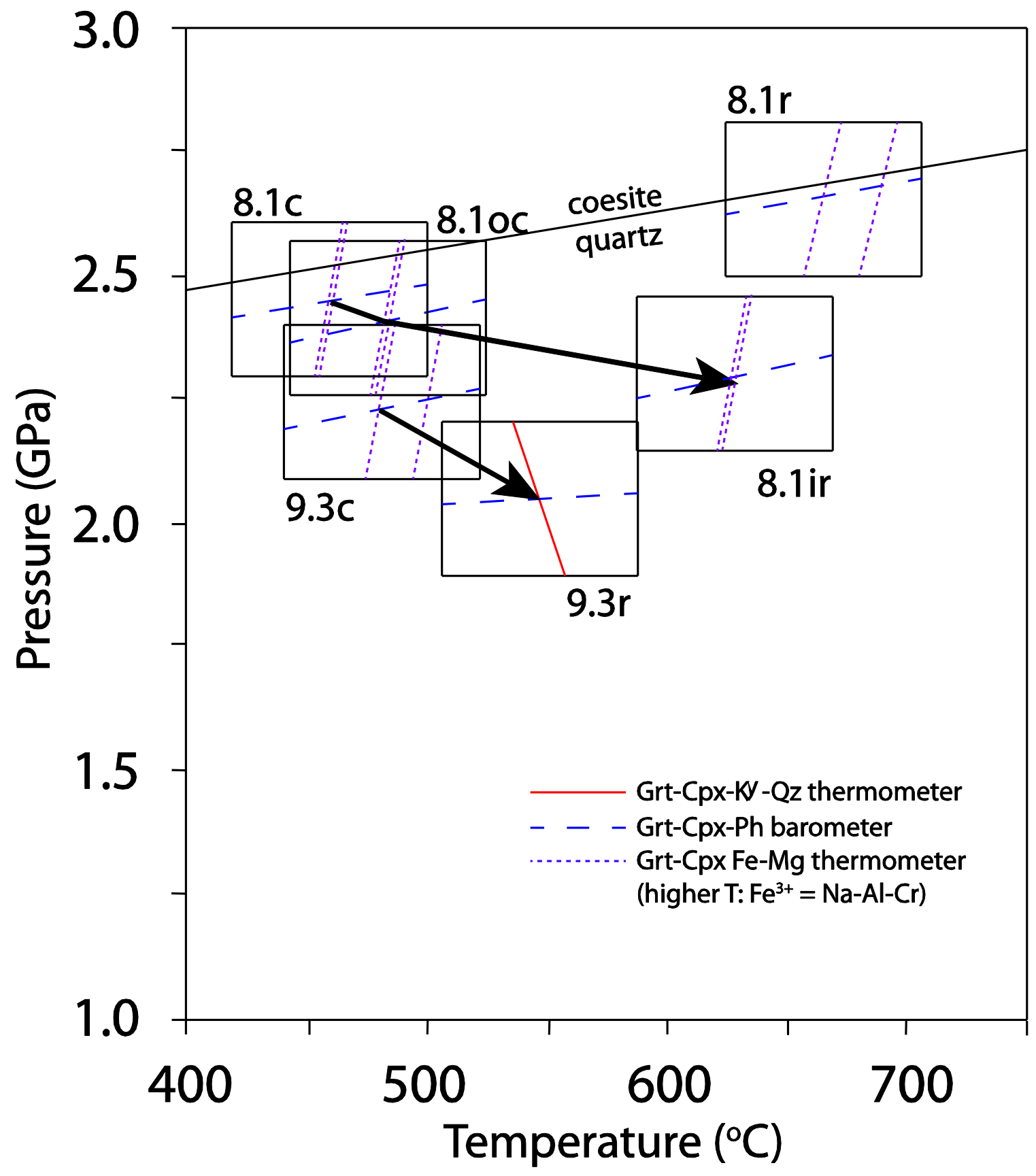



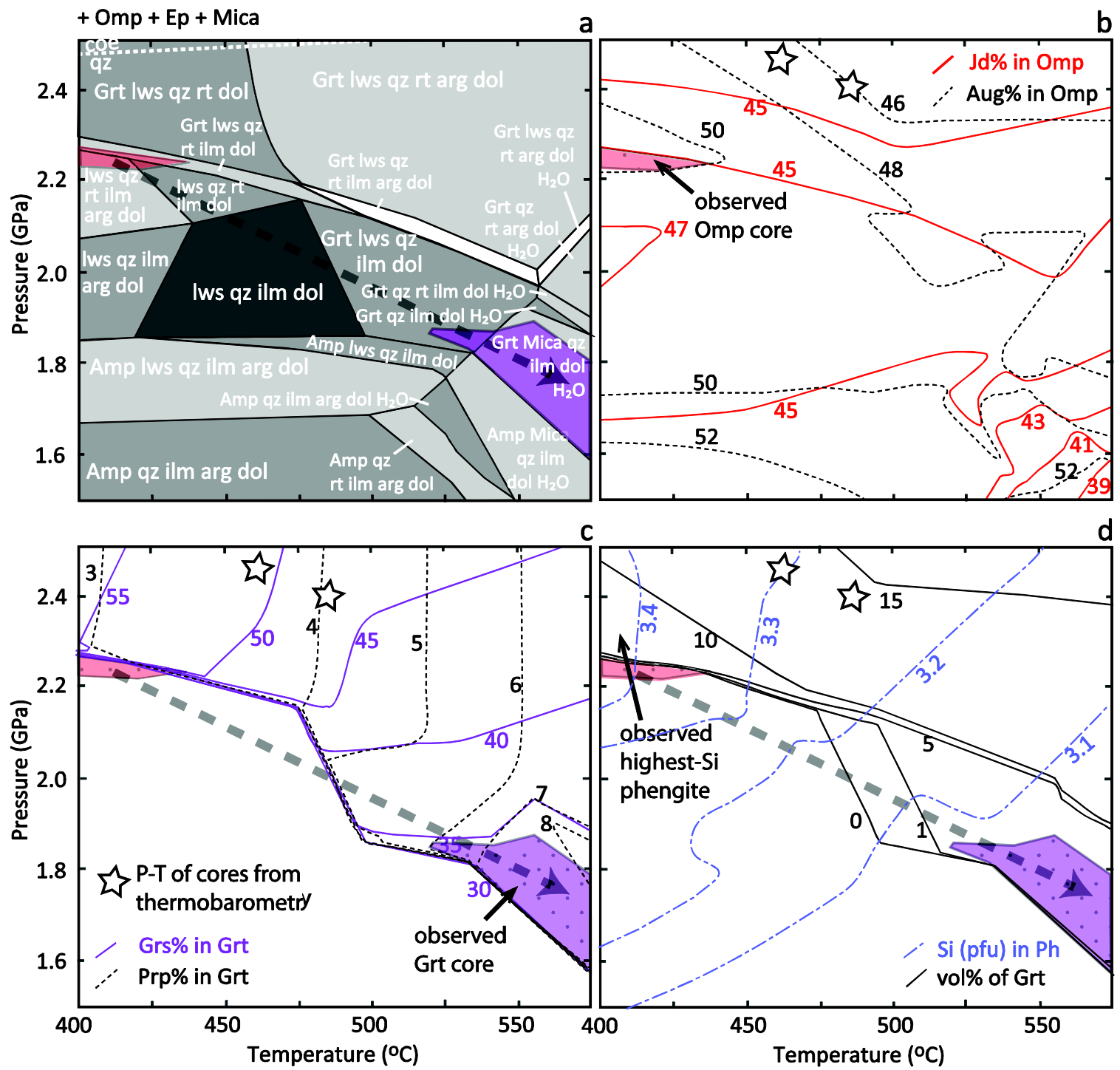


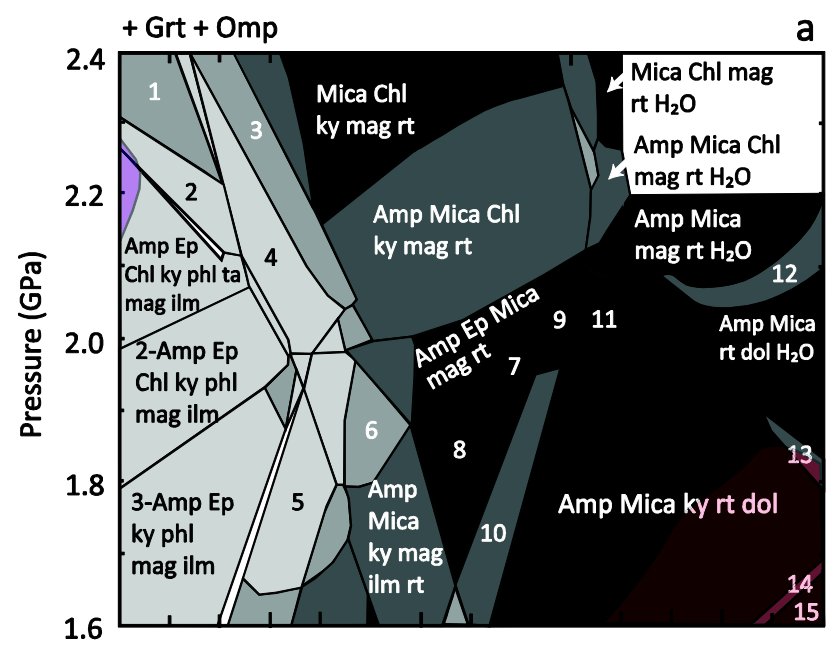
(1) Mica Chl ky phl ta mag ilm
(2) Amp Mica Chl ky ta mag ilm
(3) Amp Mica Chl ky phl mag rt
(4) Amp Mica Chl ky phl mag ilm rt
(5) 3-Amp Ep Mica ky mag ilm
(6) Amp Ep Mica ky mag ilm rt
(7) Amp Mica mag rt
(8) Amp Mica ky mag rt
(9) Amp Mica mag rt dol
(10) Amp Mica ky mag rt dol
(11) Amp Mica rt dol
(12) Amp Mica mag rt dol $\mathrm{H}_{2} \mathrm{O}$
(13) Amp Mica ky rt dol $\mathrm{H}_{2} \mathrm{O}$
(14) Amp PI Mica ky rt dol
(15) Amp PI Mica rt dol

b
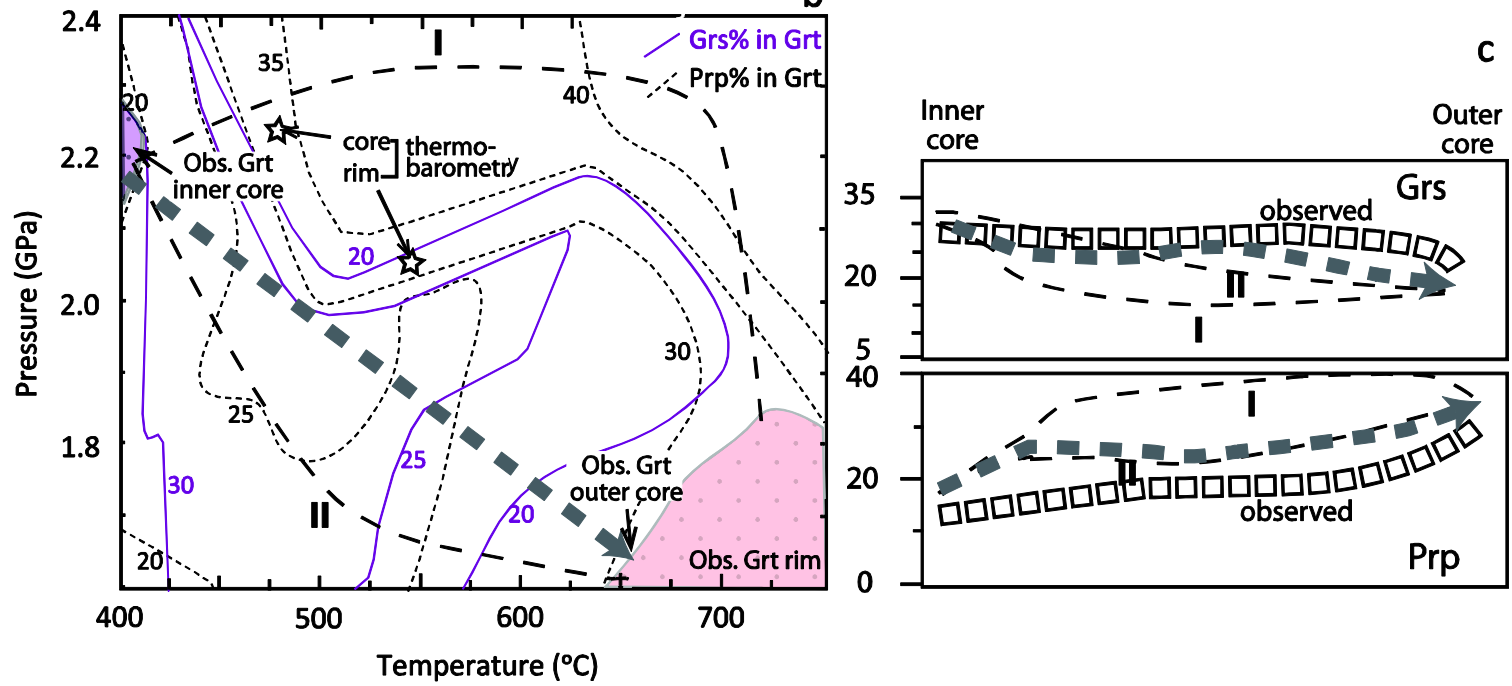
Page 53 of 56

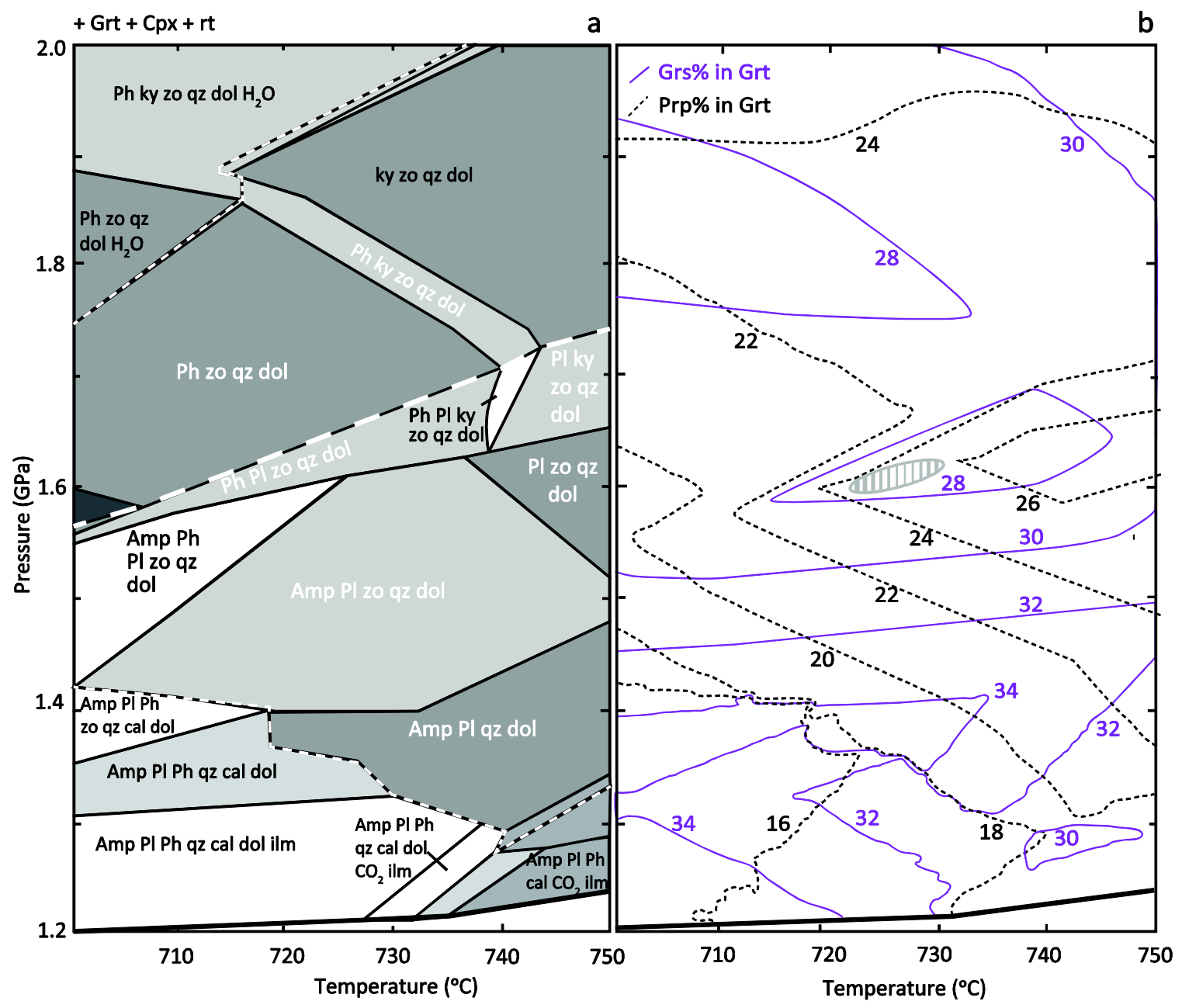


Page 54 of $\mathbf{5 6}$

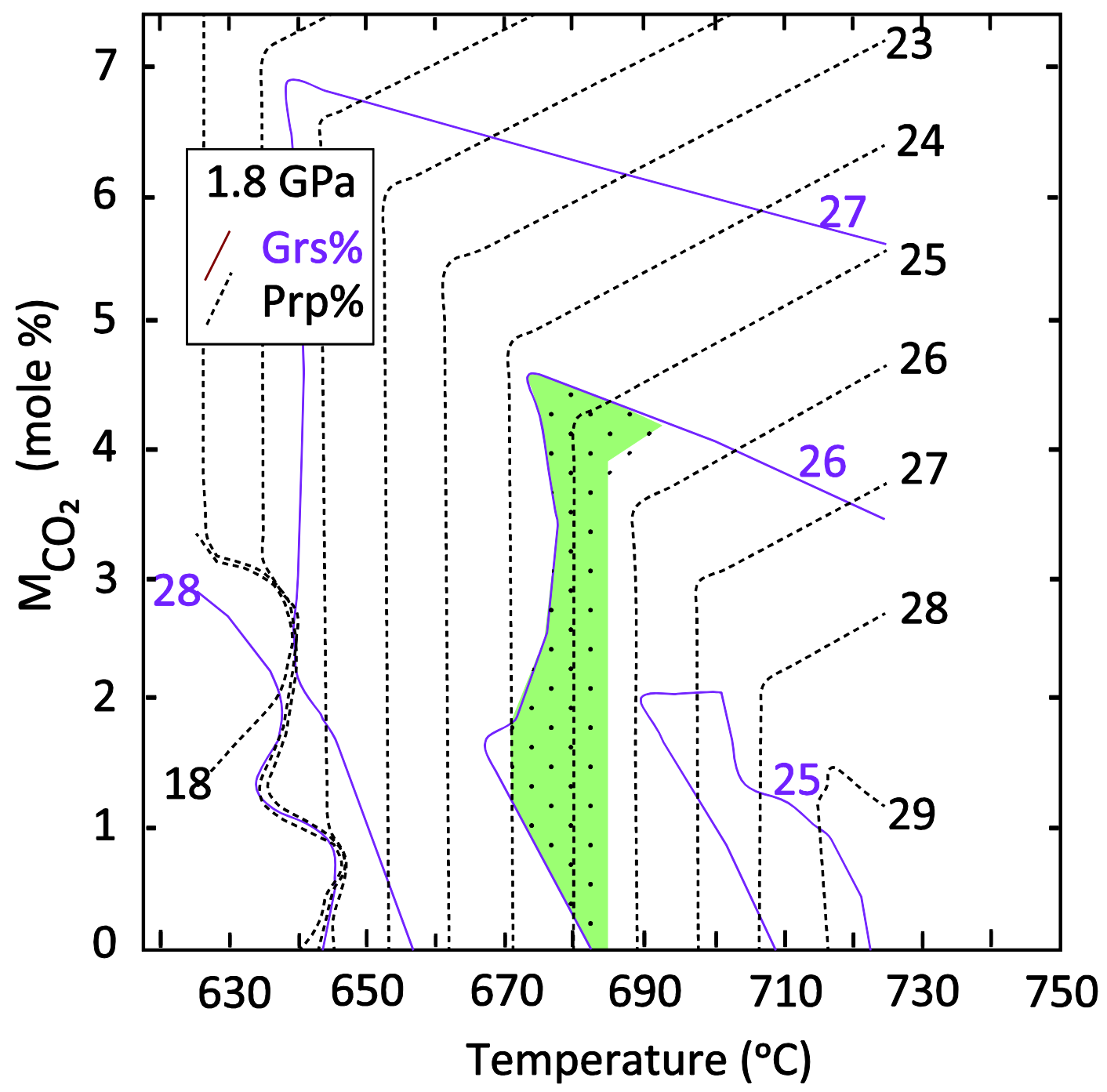




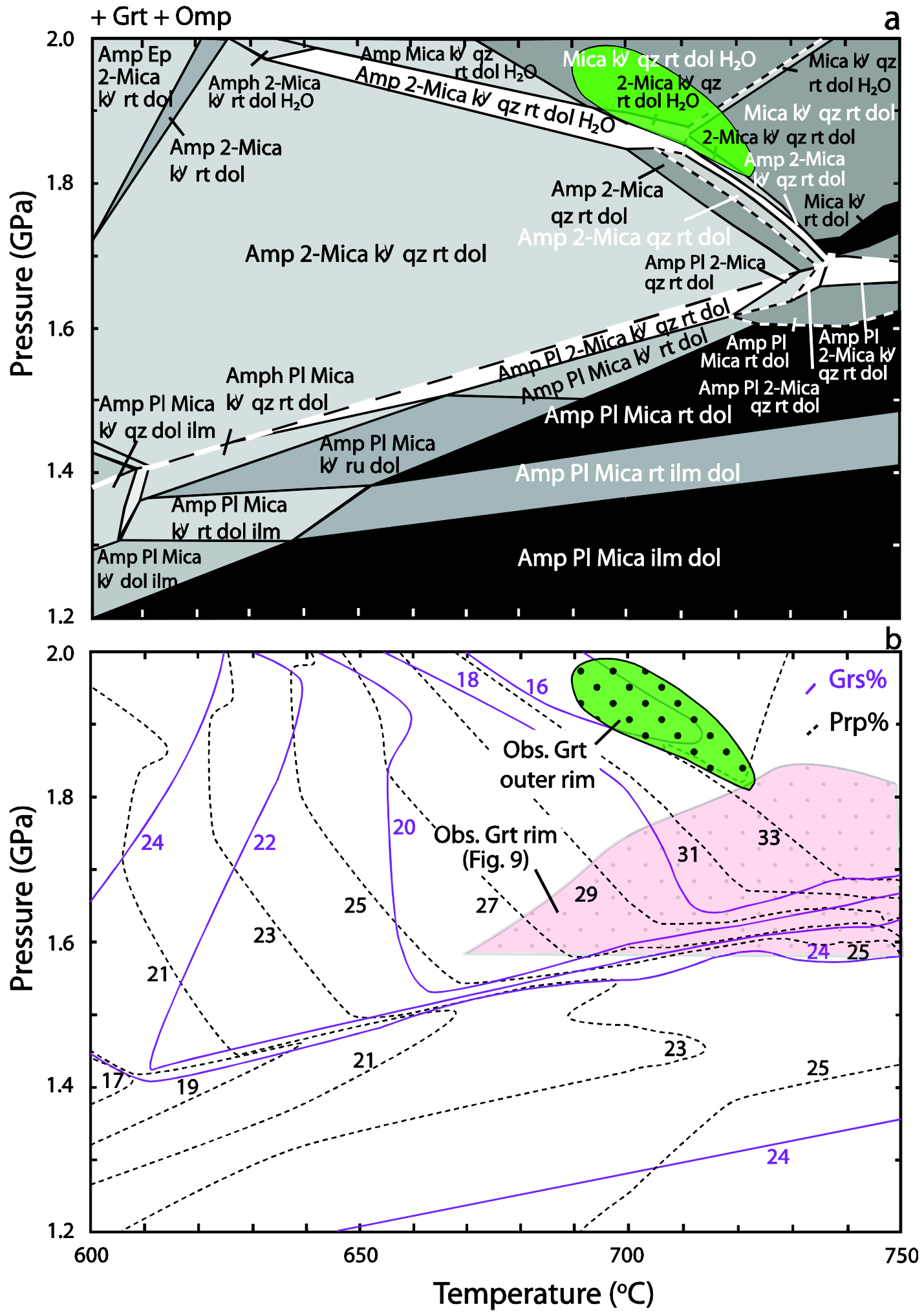



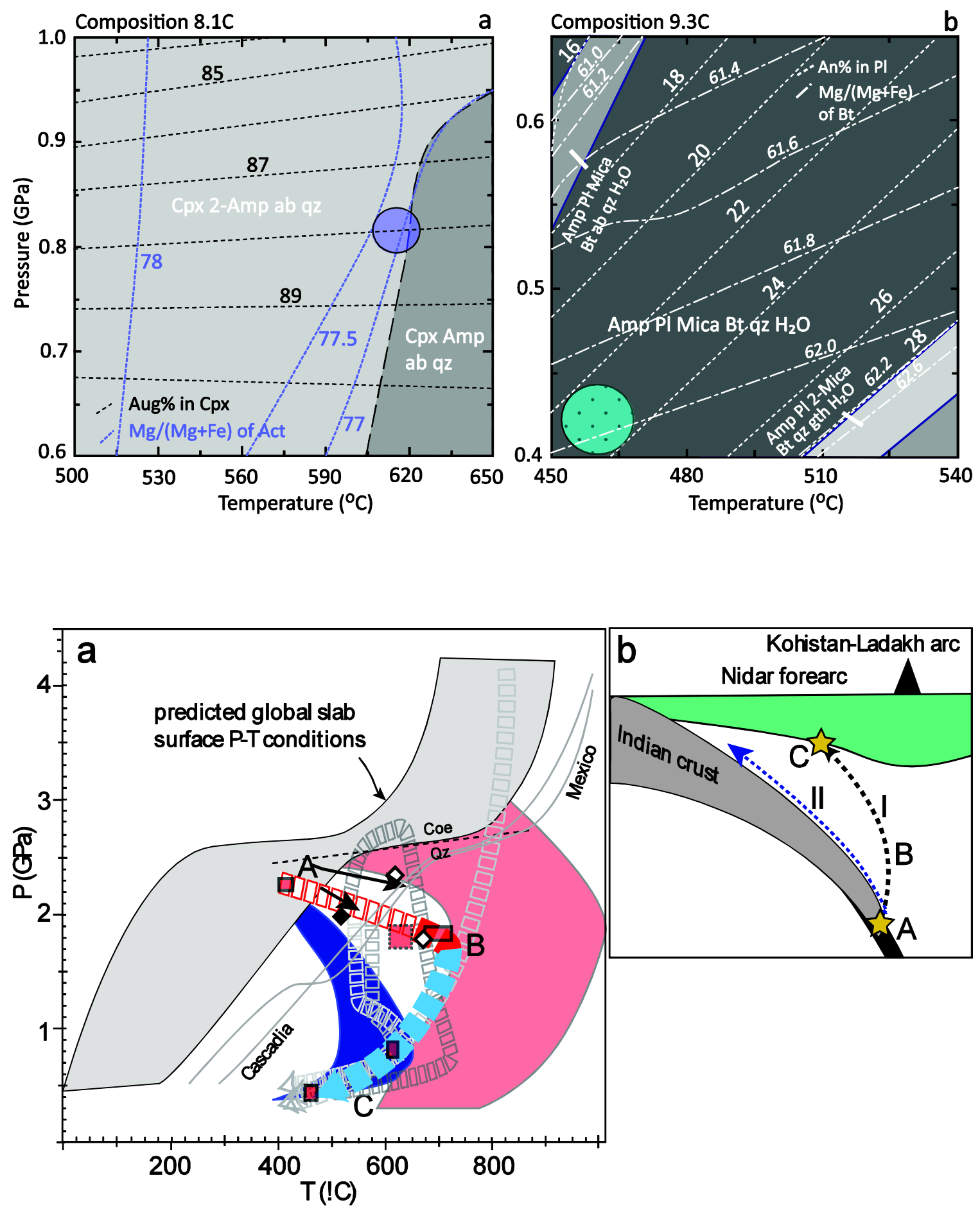